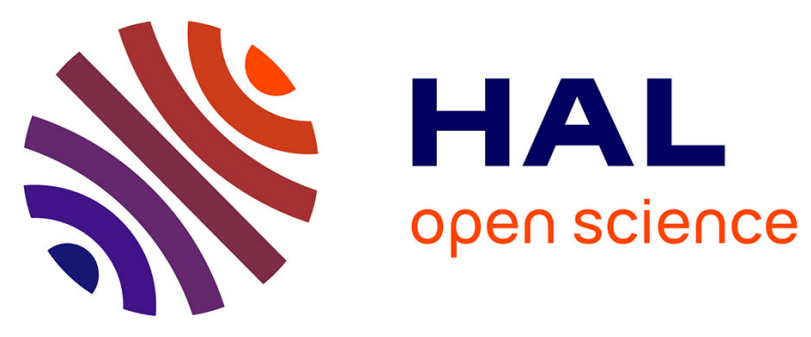

\title{
Deep crustal earthquakes in North Tanzania, East Africa: Interplay between tectonic and magmatic processes in an incipient rift
}

Julie Albaric, Jacques Déverchère, Julie Perrot, Andrey Jakovlev, Anne Deschamps

\section{To cite this version:}

Julie Albaric, Jacques Déverchère, Julie Perrot, Andrey Jakovlev, Anne Deschamps. Deep crustal earthquakes in North Tanzania, East Africa: Interplay between tectonic and magmatic processes in an incipient rift. Geochemistry, Geophysics, Geosystems, 2014, 15 (2), pp.374-394. 10.1002/2013GC005027 . insu-00985250

\section{HAL Id: insu-00985250 \\ https://hal-insu.archives-ouvertes.fr/insu-00985250}

Submitted on 29 Apr 2014

HAL is a multi-disciplinary open access archive for the deposit and dissemination of scientific research documents, whether they are published or not. The documents may come from teaching and research institutions in France or abroad, or from public or private research centers.
L'archive ouverte pluridisciplinaire HAL, est destinée au dépôt et à la diffusion de documents scientifiques de niveau recherche, publiés ou non, émanant des établissements d'enseignement et de recherche français ou étrangers, des laboratoires publics ou privés. 


\title{
Deep crustal earthquakes in North Tanzania, East Africa : Interplay between tectonic and magmatic processes in an incipient rift
}

\author{
Julie Albaric \\ Laboratory Domaines Océaniques, Université de Bretagne Occidentale, Institut Universitaire Européen de la \\ Mer, Plouzané, France
}

Now at NORSAR, Gunnar Randers vei 15, 2007 Kjeller, Norway (julie.albaric@norsar.no)

\section{Jacques Déverchère and Julie Perrot}

Laboratory Domaines Océaniques, Université de Bretagne Occidentale, Institut Universitaire Européen de la Mer, Plouzané, France

\section{Andrey Jakovlev}

Laboratory of Forward and Inverse Seismic Modeling, Institute of Petroleum Geology and Geophysics SB RAS, Novosibirsk, Russia

\section{Anne Deschamps}

Laboratory Géoazur, Université Nice Sophia-Antipolis, Observatoire de la Côte d'Azur, Géoazur, Sophia-Antipolis, France

[1] In this study, we explore the origin of lower crustal seismicity and the factors controlling rift propagation using seismological data recorded within the youngest part of the East African Rift System, the North Tanzanian Divergence (NTD). Most earthquakes below Lake Manyara occur at depth ranging between 20 and $40 \mathrm{~km}$ and have a swarm-like distribution. Focal mechanisms of 26 events indicate a combination of strikeslip and normal faulting involving Archaean basement structures and forming a relay zone. The derived local stress regime is transtensive and the minimum principal stress is oriented $\mathrm{N} 110^{\circ} \mathrm{E}$. Crustal seismic tomography reveals low-velocity anomalies below the rifted basins in the NTD, interpreted as localized thermomechanical perturbations promoting fluid release and subsequent seismicity in the lower crust. SKS splitting analysis in the NTD indicates seismic anisotropy beneath 17 stations most likely due to aligned magma lenses and/or dikes beneath the rift and to the lithospheric fabrics. Our results favor a strain pattern intermediate between purely mechanical and purely magmatic. We suggest that melt products arising from a large asthenospheric thermal anomaly enhance lithospheric weakening and facilitate faulting and creeping on critically oriented inherited structures of the Precambrian lower crust. Although the crust is unlikely weakened at a point comparable to other parts of the East African Rift System, this deep-seated thermomechanical process is efficient enough to allow slow rift propagation within the eastern Tanzanian cratonic edge.

Components: 12,526 words, 8 figures, 3 tables.

Keywords: lower crustal earthquakes; seismic swarm; East African Rift System; aseismic deformation; seismic anisotropy; seismic tomography.

Index Terms: 7270 Tomography: Seismology; 7218 Lithosphere: Seismology; 8109 Continental tectonics: extensional: Tectonophysics; 8159 Rheology: crust and lithosphere: Tectonophysics; 8180 Tomography: Tectonophysics; 8178 Tectonics and magmatism: Tectonophysics. 
Received 4 September 2013; Revised 16 December 2013; Accepted 17 December 2013; Published 6 February 2014.

Albaric, J., J. Déverchère, J. Perrot, A. Jakovlev, and A. Deschamps (2014), Deep crustal earthquakes in North Tanzania, East Africa: Interplay between tectonic and magmatic processes in an incipient rift, Geochem. Geophys. Geosyst., 15, 374394, doi:10.1002/2013GC005027.

\section{Introduction}

[2] The East African Rift System (EARS) offers the rare opportunity to study the different stages of continental extension, from its initiation in the North Tanzanian Divergence (NTD; Figure 1) to oceanic accretion in Afar. The dynamics of the EARS has been linked to the effect of one or several mantle plumes [Burke, 1996; Ebinger and Sleep, 1998; Nyblade et al., 2000; Pik et al., 2006; Hansen et al., 2012; Mulibo and Nyblade, 2013a, 2013b]. In mature stages of rifting, continental breakup documented in Afar and Ethiopian rift regions is mainly controlled by magmatic processes, with the occurrence of large dike-opening events [e.g., Wright et al., 2006]. In contrast, it is unclear how strain accommodation is partitioned between faulting and magmatism in immature stages like in the NTD or in other tips of the EARS. On the one hand, the relatively small amount of surface volcanism observed in the NTD region [Dawson, 1992] and the reported seismic activity of some large border faults [Ebinger et al., 1997, 1999; Mulibo and Nyblade, 2009] suggest fault-dominated deformation mechanisms such as those described in rifting models where faulting plays a major role until the lithosphere has been thinned enough [Corti, 2009, and references therein]. On the other hand, recent seismic and geodetic surveys performed ca. $100 \mathrm{~km}$ north of the NTD, in the Lake Natron area (Figure 1), indicate that significant surface deformations are caused by magmatic injections [Calais et al., 2008]. This observation suggests that similar seismo-magmatic events could occur in the NTD, in particular at large depths where their detectability is declining. The lithosphere under the NTD is indeed relatively thick and rigid because of the presence of the Tanzanian craton [Le Gall et al., 2008; Perez-Gussinyé et al., 2009].

[3] A common related question is the meaning of deep crustal earthquakes often reported in modern continental rifts [Bungum and Nnko, 1984; Camelbeeck and Iranga, 1996; Déverchère et al., 2001; Reyners et al., 2007; Keir et al., 2009; Albaric et al., 2010; Lindenfeld et al., 2012]: their occurrence requires a highly resistant mafic lower crust
[Shudovsky et al., 1987; Nyblade and Langston, 1995; Albaric et al., 2009], but which factors control this stress release remains unclear. Do they primarily result from large zones of weakness (as suture zones, cratonic border faults or other zones of lower shear strength than surrounding rocks) within strong crust [e.g., Lyakhovsky et al., 2012; Fagereng, 2013]? Or are they triggered by fluids settled within critically loaded shear zones [e.g., Reyners et al., 2007; Lindenfeld et al., 2012] or by magmatic processes below/within the crust [e.g., Keir et al., 2009; Thybo and Nielsen, 2009; Schmeling and Wallner, 2012]?

[4] From a seismic monitoring of the NTD conducted during 6 months in 2007, we have observed that a significant part of the seismicity occurs in the lower crust and clusters below Lake Manyara [Albaric et al., 2010]. In this paper, we perform several analyses based on seismological data in order to investigate (1) the triggering mechanisms of this deeply rooted and long-duration seismicity and (2) the respective roles of magmatism and crustal fabrics for rift initiation in the NTD. Thanks to our dense temporary seismological network, we characterize the seismogenic deformation in great detail (focal mechanisms, stress inversion) and explore how it is related to crustal velocity anomalies (seismic tomography) and to deeper processes occurring in the lithosphere (seismic anisotropy).

\section{Tectono-Volcanic Setting}

[5] The EARS corresponds to the divergent boundary between two main tectonic plates, the Nubian and Somalian plates, and several microplates [Calais et al., 2006]. The rift continues more than $4000 \mathrm{~km}$ from the Afar triple junction in the north to Mozambique in the South. The EARS has started developing in the north, as attested by the age of the volcanic samples collected in the Ethiopian rift (40-45 Ma) [George et al., 1998]. The most recent volcano-tectonic activity in the EARS is found in the NTD (8-5 Ma) [after Dawson, 1992] (Figure 1), with a clear shift of magmatic activity eastward between 5 and 


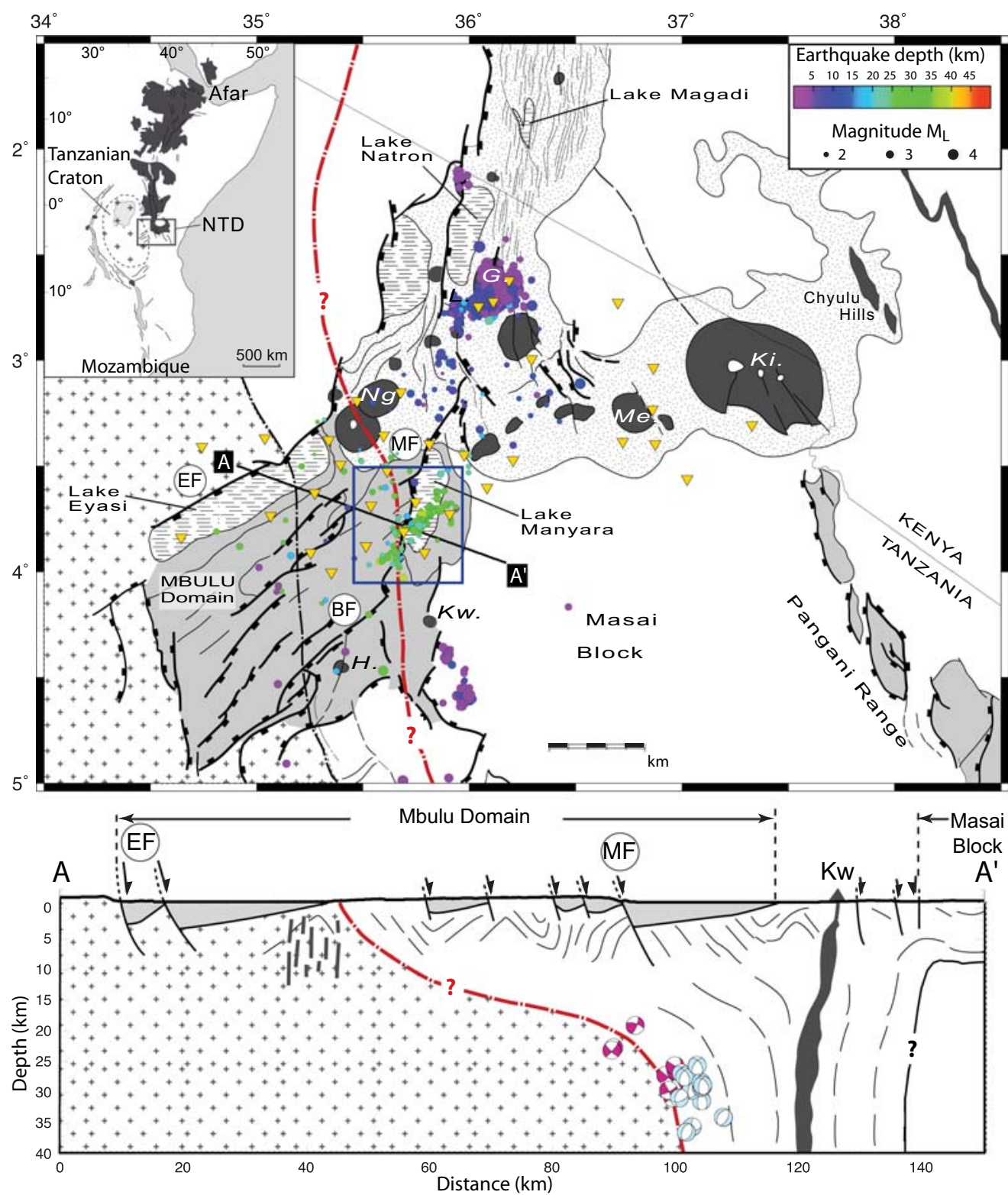

\begin{tabular}{|lllll}
\hline M & Major sedimentary areas & Rift-involved basement
\end{tabular}

Figure 1. Simplified geological map of the (top) North Tanzanian Divergence and (bottom) cross section along segment A-A'. Colored circles correspond to the seismicity recorded between June and December 2007 by 35 stations (triangles) (location from Albaric et al. [2010]). Focal mechanisms computed in this study are projected on the A-A' section. Volcanic edifices: G., Gelai; H., Hanang; Ki., Kilimanjaro; Kw., Kwaraha; L., Oldoinyo Lengai; Me, Meru; Ng, Ngorongoro. Faults: BF, Balangida; EF, Eyasi; and MF, Manyara (adapted from Albaric et al. [2010]).

$0 \mathrm{Ma}$, up to the eastern part of the Kilimanjaro edifice [Nonnotte et al., 2008].

[6] The EARS splits into two branches, the western and eastern branches, around the Archaean Tanzanian craton and propagates into its margins, the accreted Proterozoic belts, at ultraslow (ca. 2 $\mathrm{mm} / \mathrm{yr}$ ) extension rates [Calais et al., 2006; Stamps et al., 2008]. The crust has undergone only slight thinning below the rift valley and is about $\sim 35 \mathrm{~km}$ thick in south Kenya [Birt et al., 1997] and $\sim 37 \mathrm{~km}$ thick in north Tanzania [Last et al., 
1997]. The NTD is the southern part of the Eastern branch of the EARS (Figure 1). In this region, the EARS develops into the craton, despite the thick and highly resistant lithosphere [Petit and Ebinger, 2000; Pérez-Gussinyé et al., 2009]. A spectacular change in the morphotectonic and magmatic expressions of the EARS is observed in the NTD (Figure 1), which has been attributed to the presence of the Tanzanian craton [Dawson, 1992; Ebinger et al., 1997; Le Gall et al., 2008]. The rift splits into three branches (namely, the Eyasi, Manyara, and Pangani rifts) around the rigid and relatively undeformed Masai block [Ebinger et al., 1997; Le Gall et al., 2008]. The orientation of the rift changes from N-S in South Kenya (Natron rift) to NNE-SSW (Manyara rift), NE-SW (Eyasi and Balangida rifts), and NWSE (Pangani rift) in the NTD (Figure 1). The Mbulu domain locates in-between the Eyasi and Manyara rifts and presents a $\sim$ NE-SW structural grain associated with underlying basement structures [Ebinger et al., 1997; Le Gall et al., 2008]. Multiple collisional events have actually affected the craton margin [Smith and Mosley, 1993], and the location of its boundary with the Proterozoic Mozambique belt is uncertain (Figure 1) [Ebinger et al., 1997].

[7] The lithospheric mantle under the NTD is thermally modified [Ritsema et al., 1998; Weeraratne et al., 2003; Huerta et al., 2009], accounting for many thermal springs rising in the region (see the compilation from Macheyeki et al. [2008]; Figure 2 ). Despite the evidence for an anomalous uppermantle structure below the eastern branch from 100 to $1200 \mathrm{~km}$ [Mulibo and Nyblade, 2013a] and from 68 to $218 \mathrm{~km}$ [O'Donnell et al., 2013], it is still unclear how it extends at shallower depths. The crust in the NTD is actually characterized by low surface heat flow values [Nyblade et al., 1990] whereas surface volcanism is abruptly decreasing south of the transverse Ngorongoro-Meru-Kilimanjaro volcanic belt (only a few volcanoes in or at the limit with the craton, e.g., Kwaraha and Hanang, Figure 1).

\section{Seismic Monitoring}

[8] We have deployed a network of 35 threecomponent seismic stations from June to November 2007, and four stations from November 2007 to January 2008 in the Natron area (Figure 1). More than 2000 earthquakes were located and concentrate south of Lakes Natron and Manyara (data processing detailed in Albaric et al. [2010]). The seismicity recorded at Natron is related to the volcano-tectonic activity under the Lengai and Gelai volcanoes [ $\mathrm{Cal}$ ais et al., 2008; Albaric et al., 2010]. The earth- quake sequence located south of Lake Manyara consists of 211 events distributed between about 15 and $40 \mathrm{~km}$ depth and along $\sim \mathrm{NE}-\mathrm{SW}$ direction. All the events were located using a 1-D velocity model extracted from several studies in the area [see Albaric et al., 2010, and references therein]. The mean absolute location error is about $\pm 3.0 \mathrm{~km}$ and smaller in the Manyara region because earthquakes are just below the seismic network $( \pm 1.5,1.2$, and $\pm 1.9 \mathrm{~km}$, in latitude, longitude, and depth, respectively; Figure 2). The earthquakes below Manyara were relocated using the double-difference method of Waldhauser and Ellsworth [2000] (Figure 2) [Albaric et al., 2010]. Most of the seismicity consists of typical tectonic events (high frequency content, Figure 2) but some hybrid events have been identified at Gelai, during the volcano-tectonic crisis [Albaric et al., 2010]. Local magnitudes $M_{L}$ were determined using the relation of Hutton and Boore [1987], $M_{L}=a^{*} \log (A)+b^{*} \log (D)+c^{*} D+d$, where $A$ is the maximum displacement amplitude and $D$ is the epicentral distance. The values of the coefficients $a(0.925), b(0.91), c(-1.31)$ come from ESARSWG (Eastern and Southern African Regional Seismological Working Group) [Hollnack and Stangl, 1998]. The frequency-magnitude distribution indicates a magnitude of completeness of 2.1. The $b$ value, estimated from maximum likelihood method is 1.06 [Aki, 1965].

[9] Intense seismic activity has already been observed in the Manyara region thanks to a regional network deployed between 1994 and 1995 [Nyblade et al., 1996]. Events with extensional focal mechanisms were dominant in this period and were interpreted as associated with normal slip on the NNE-directed Manyara rift border fault [Mulibo and Nyblade, 2009]. Conversely, NE-SW deeply rooted structures are also suspected to be involved in the seismic activity we recorded at Manyara [Albaric et al., 2010]. Here we investigate for the first time in details the focal mechanisms and related local stress field of the Manyara cluster. Furthermore, the whole database is used to perform a local seismic tomography of the crust. We also assess the deep lithospheric structure under the 2007 stations through SKS splitting measurements performed on teleseismic events.

\section{Focal Mechanisms and Local Stress Field}

\subsection{Fault Plane Solutions}

[10] We have computed focal mechanisms of earthquakes belonging to the Manyara cluster, 


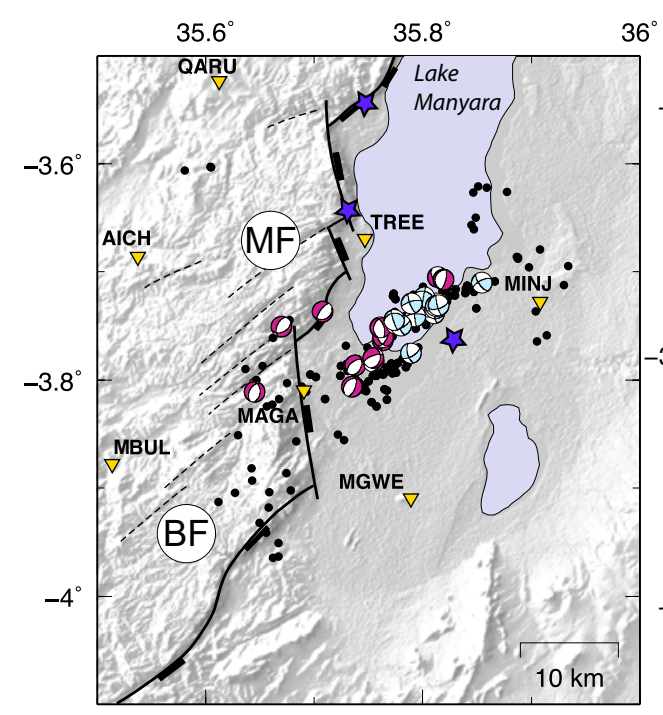

$36^{\circ}$

$35.75^{\circ}$

$35.8^{\circ}$

$35.85^{\circ}$

Hydrothermal sources

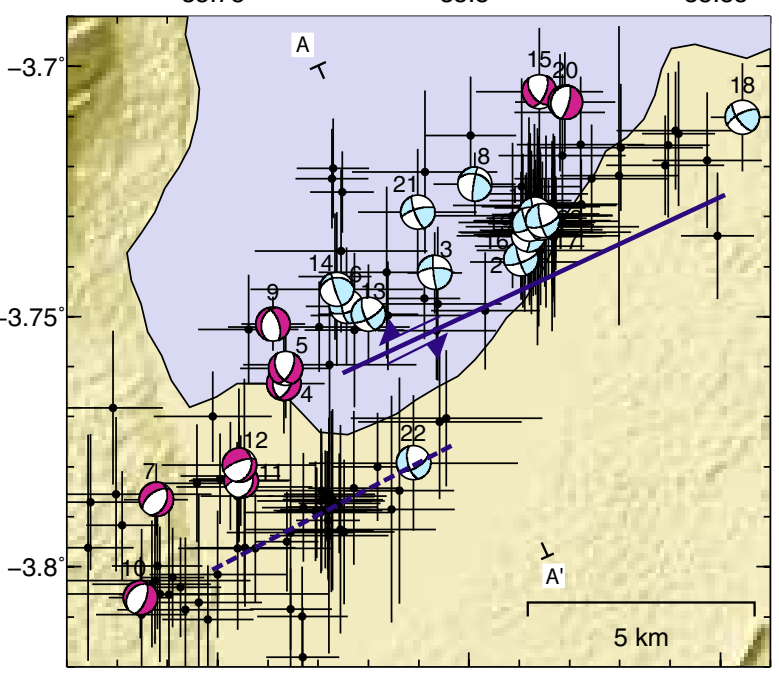

A-A' N155ㅌ
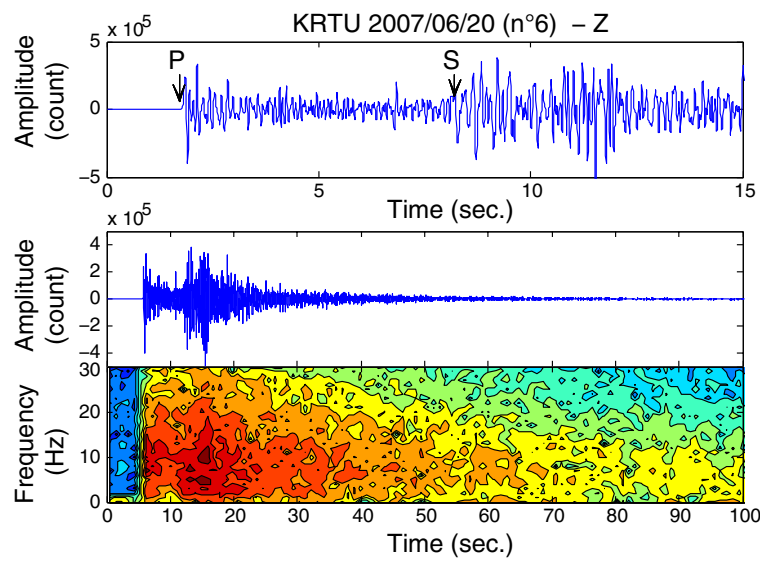

20

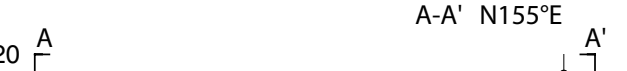

Power Spectral Density (count2/Hz)
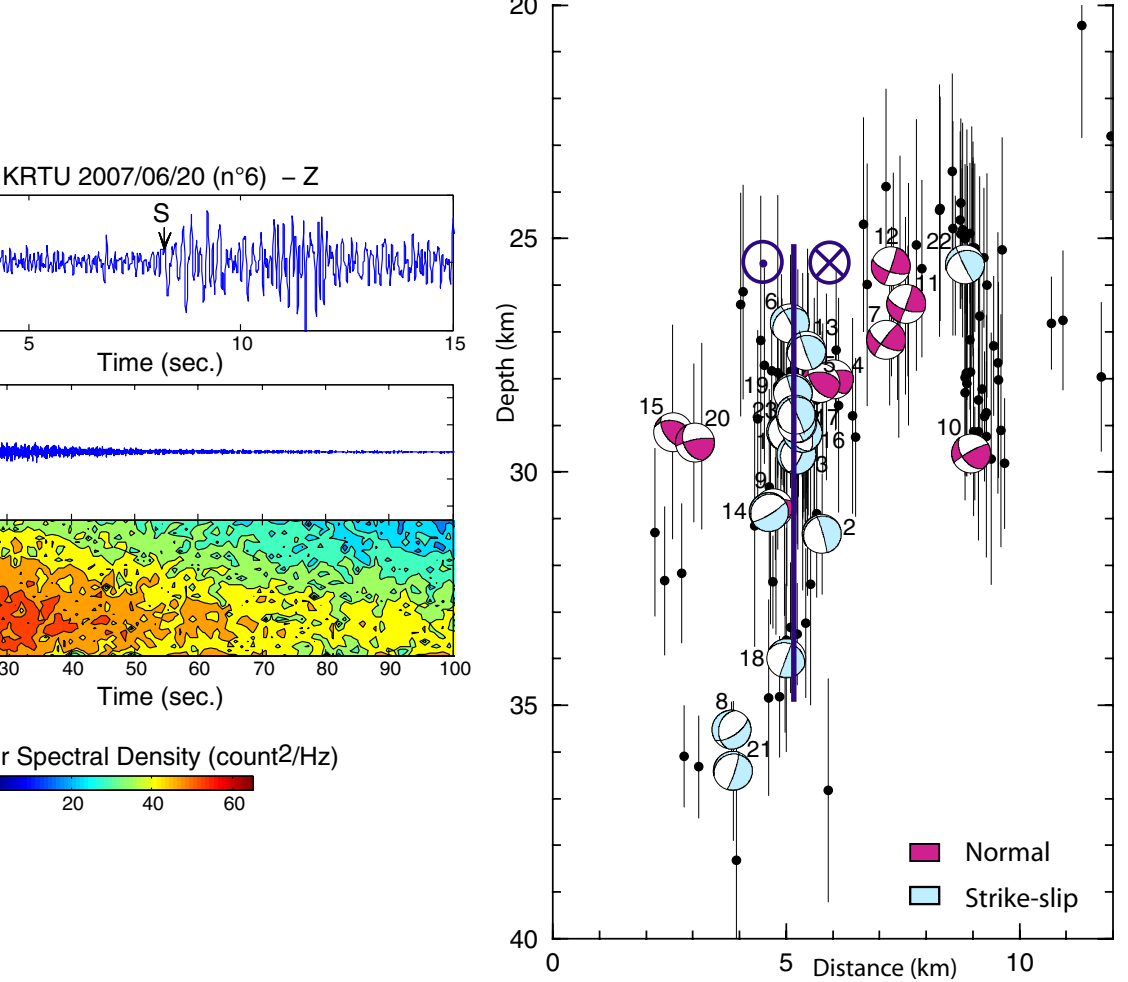

Figure 2. Seismicity distribution (black circles on maps and cross section $A-A^{\prime}$ ) located in the Manyara region (relocation from Albaric et al. [2010]) and example of an earthquake recorded at KRTU station (see Figure 8 for station names). The black bars represent the absolute location error. Focal mechanisms are numbered (Figure 3 and Table 1) and distinguished by a color code according to the faulting motion, either strike slip (blue) or normal (pink). The blue line (top right map and cross section A-A') refers to the left lateral strike-slip fault associated with the strike-slip focal mechanisms. The data example includes a seismogram zoomed on $P$ and $S$ wave onsets (arrows), the whole earthquake record (100 s) and the corresponding spectrogram.

using the code HASH from Hardebeck and Shearer [2002]. $P$ wave first motion polarities were picked manually on unfiltered waveforms recorded on vertical components (Figure 2). A set of acceptable mechanisms fitting the polarities is returned for each event (black lines in Figure 3) 


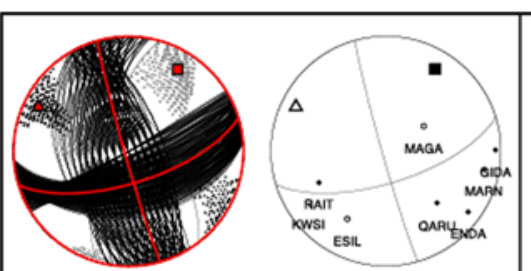

1 -- 20070609 10:29
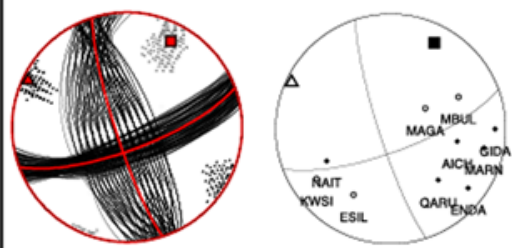

2 -- 20070610 04:04
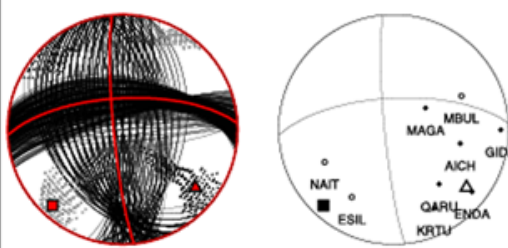

3 -- $2007061223: 20$
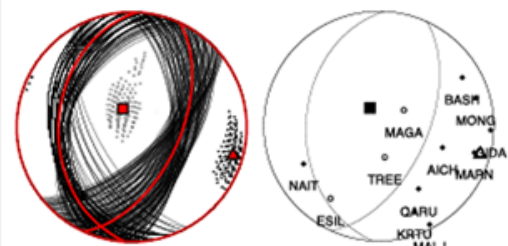

4 -- $2007061617: 24$
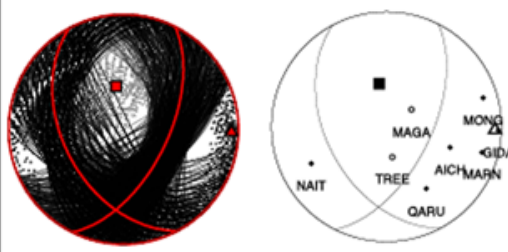

5 -- $2007061617: 33$
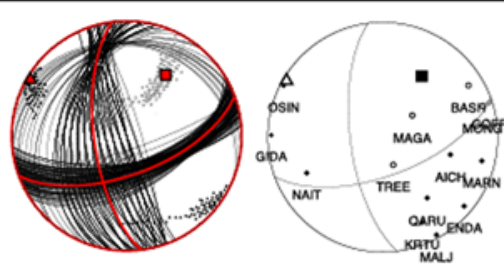

6 -- $20070620 \quad 02: 13$

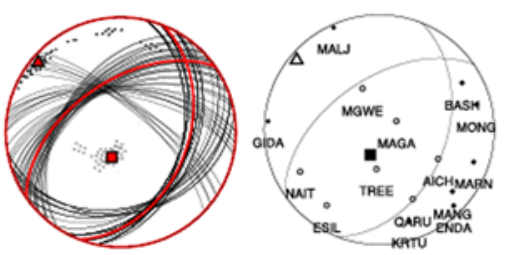

7 -- 20070705 01:13
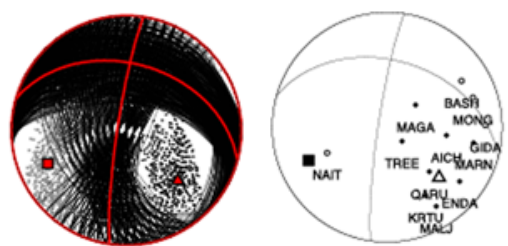

8 -- 20070710 11:52
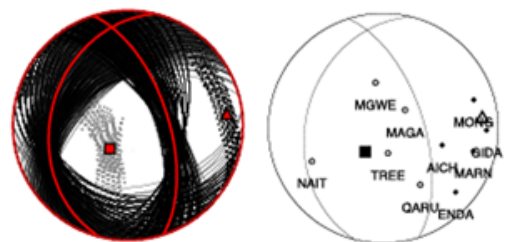

9 -- $2007071120: 45$
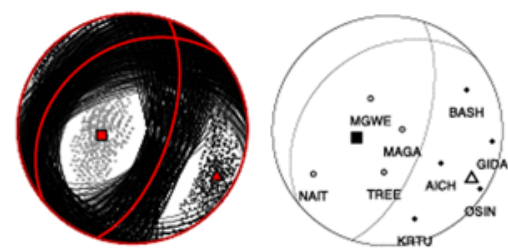

10 -- $2007071322: 32$

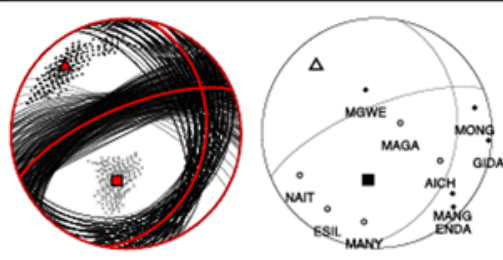

11 -- 20070813 12:00
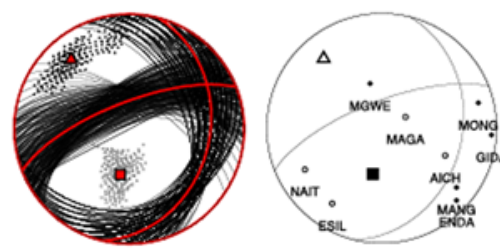

12 -- 20070813 13:27
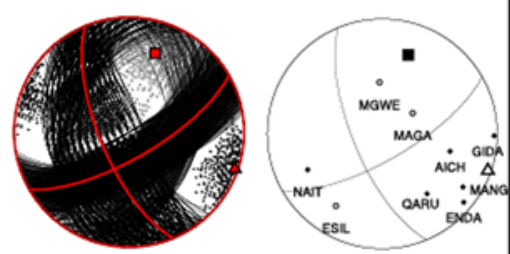

13 -- 20070822 22:06
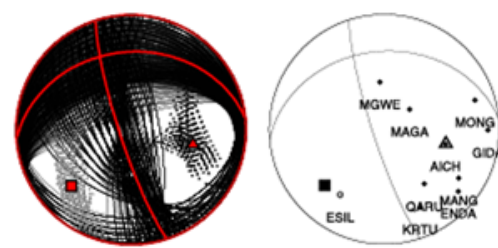

14 -- $2007082701: 31$
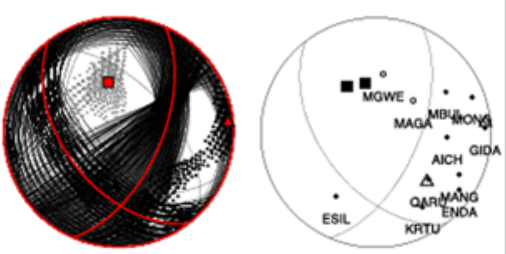

15 -- 20070830 13:55

$\Delta \Delta$ Taxis
$\square$ - P axis

Taxes acc

- Positive polarity

- Negative polarity

Figure 3. Focal mechanisms of 26 earthquakes of the Manyara sequence. For each event, the left diagram includes acceptable (black lines) and preferred (red lines) mechanisms, and corresponding $\mathrm{P}$ and $\mathrm{T}$ axes; the right diagram includes the preferred mechanism, the associated $\mathrm{P}$ and $\mathrm{T}$ axes and the distribution of the polarities observed at each station.

depending on the expected errors in takeoff angles. The takeoff angles were computed for a 1-D velocity model derived from the bibliography [see
Albaric et al., 2010, and references therein]. A preferred mechanism (red line in Figure 3) is computed from the average of the set of acceptable 


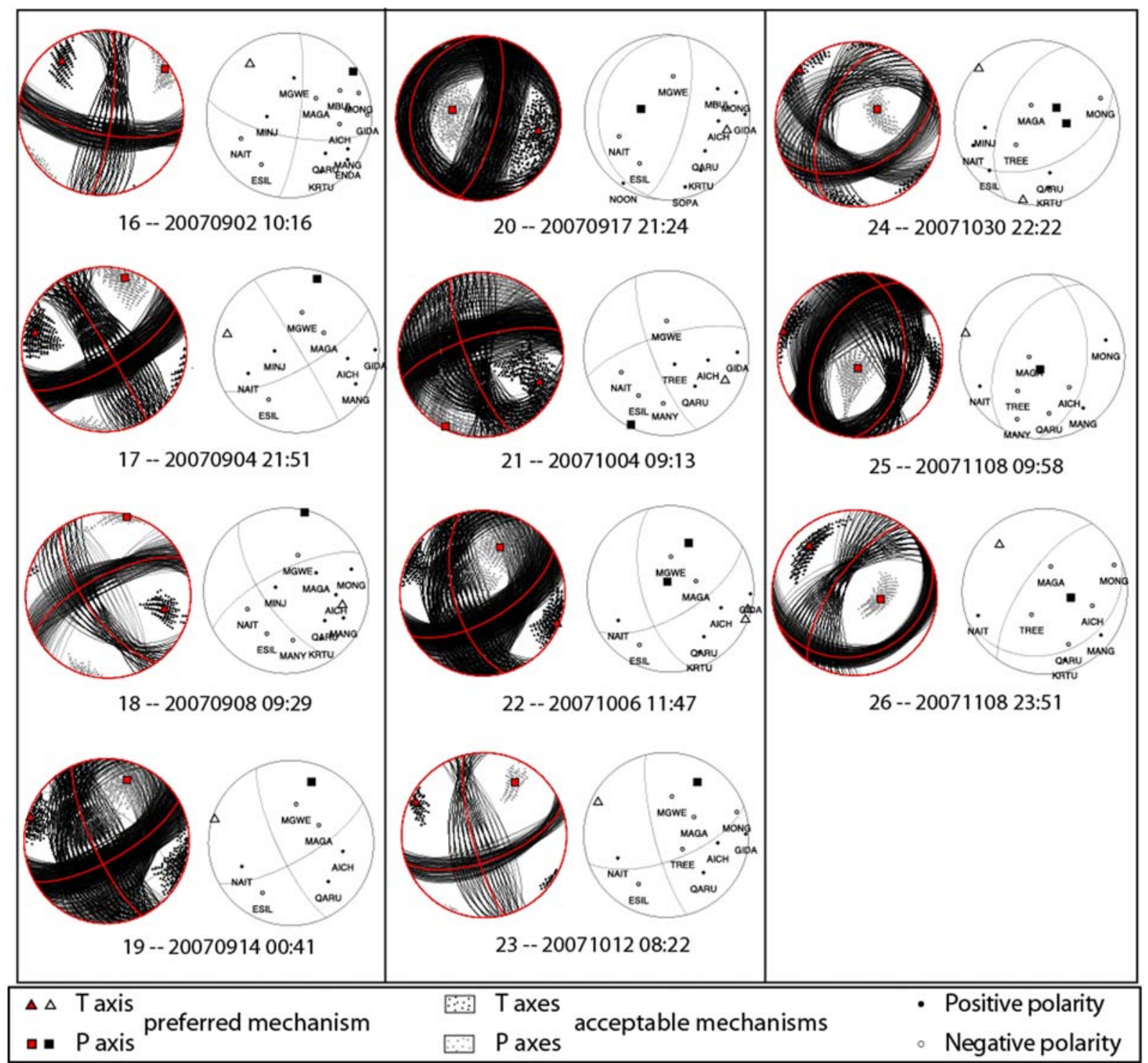

Figure 3. (Continued)

mechanisms whose distribution, tight or scattered around the preferred mechanism, indicates the quality of the solution. The uncertainty of the preferred and acceptable nodal planes is quantified by the fault plane uncertainty (FPU), which is the root mean square (RMS) angular difference between acceptable and preferred mechanisms (Table 1). We consider the solutions associated with a FPU smaller than $35^{\circ}$ and a minimum of $60 \%$ of the acceptable mechanisms being within $35^{\circ}$ angular distance from the preferred mechanism. We obtain 26 focal mechanisms showing predominantly normal or strike-slip motions, which locations in the Lake Manyara region are presented in Figure 2.
[11] The solutions are quite similar within each group of focal mechanisms: the nodal planes strike mainly $\sim \mathrm{N} 20^{\circ} \mathrm{E}$ in the case of normal faulting, and $\sim \mathrm{N} 65^{\circ} \mathrm{E}$ or $\mathrm{N} 160^{\circ} \mathrm{E}$ for strike-slip mechanisms (Figure 4a). This similarity, which can be expected for events closely clustered in space and time, is an indication of the consistency of the results. In order to distinguish the fault plane among the nodal planes, we have compared the spatial distribution of the focal mechanisms to the rest of the seismicity and to surface tectonics (Figure 2).

[12] The area is characterized by two main faults, the highly segmented Manyara fault and the 
Table 1. Description of the Focal Mechanisms of 26 Earthquakes Recorded South of Lake Manyara ${ }^{a}$

\begin{tabular}{|c|c|c|c|c|c|c|c|c|c|c|c|c|c|c|c|c|}
\hline ID & Date & Year, & Month, & , Day, & $\mathrm{HH}: \mathrm{I}$ & [M:SS) & $\begin{array}{l}\text { Latitude } \\
\quad\left({ }^{\circ}\right)\end{array}$ & $\begin{array}{c}\text { Longitude } \\
\left(^{\circ}\right)\end{array}$ & $\begin{array}{l}\text { Depth } \\
(\mathrm{km})\end{array}$ & $\begin{array}{c}\text { Str1 } \\
\left({ }^{\circ}\right)\end{array}$ & $\begin{array}{l}\text { Dip } \\
\left({ }^{\circ}\right)\end{array}$ & $\begin{array}{l}\text { Rake } \\
\left({ }^{\circ}\right)\end{array}$ & $\begin{array}{l}\text { FPU1 } \\
\left(^{\circ}\right)\end{array}$ & $\begin{array}{c}\text { FPU2 } \\
\left({ }^{\circ}\right)\end{array}$ & Npol & $\mathrm{M}_{\mathrm{L}}$ \\
\hline 1 & 2007 & 6 & 9 & 10 & 29 & 23.520 & -3.72950 & 35.81317 & 29.140 & 164 & 87 & -157 & 21 & 14 & 8 & 1.8 \\
\hline 2 & 2007 & 6 & 10 & 4 & 4 & 24.410 & -3.73850 & 35.81033 & 31.330 & 162 & 81 & -164 & 18 & 8 & 10 & 2.2 \\
\hline 3 & 2007 & 6 & 12 & 23 & 20 & 59.150 & -3.74117 & 35.79317 & 29.630 & 174 & 84 & 158 & 29 & 12 & 9 & 1.8 \\
\hline 4 & 2007 & 6 & 16 & 17 & 24 & 57.800 & -3.76333 & 35.76317 & 28.010 & 183 & 36 & -108 & 12 & 15 & 12 & 2.8 \\
\hline 5 & 2007 & 6 & 16 & 17 & 33 & 38.290 & -3.76033 & 35.76350 & 28.090 & 152 & 46 & -134 & 25 & 22 & 8 & 1.8 \\
\hline 6 & 2007 & 6 & 20 & 2 & 13 & 15.700 & -3.74800 & 35.77567 & 26.820 & 173 & 67 & -150 & 28 & 8 & 14 & 3.6 \\
\hline 7 & 2007 & 7 & 5 & 1 & 13 & 11.200 & -3.78650 & 35.73783 & 27.170 & 21 & 41 & -117 & 17 & 28 & 15 & 2.8 \\
\hline 8 & 2007 & 7 & 10 & 11 & 52 & 54.430 & -3.72350 & 35.80117 & 35.520 & 189 & 84 & 131 & 27 & 19 & 12 & 2.8 \\
\hline 9 & 2007 & 7 & 11 & 20 & 45 & 42.810 & -3.75150 & 35.76100 & 30.780 & 194 & 33 & -62 & 26 & 14 & 10 & 2.4 \\
\hline 10 & 2007 & 7 & 13 & 22 & 32 & 5.620 & -3.80617 & 35.73466 & 29.600 & 19 & 63 & -104 & 17 & 22 & 9 & 2.7 \\
\hline 11 & 2007 & 8 & 13 & 12 & 0 & 21.600 & -3.78283 & 35.75467 & 26.400 & 11 & 32 & -142 & 16 & 15 & 10 & 2.8 \\
\hline 12 & 2007 & 8 & 13 & 13 & 27 & 55.790 & -3.77967 & 35.75433 & 25.590 & 14 & 31 & -141 & 16 & 15 & 9 & 3.1 \\
\hline 13 & 2007 & 8 & 22 & 22 & 6 & 55.350 & -3.74950 & 35.78000 & 27.410 & 158 & 69 & -159 & 26 & 22 & 9 & 2.5 \\
\hline 14 & 2007 & 8 & 27 & 1 & 31 & 31.550 & -3.74450 & 35.77367 & 30.860 & 162 & 82 & 122 & 18 & 25 & 10 & 3.0 \\
\hline 15 & 2007 & 8 & 30 & 13 & 55 & 23.280 & -3.70500 & 35.81400 & 29.150 & 142 & 51 & -139 & 29 & 25 & 11 & 3.7 \\
\hline 16 & 2007 & 9 & 2 & 10 & 16 & 34.410 & -3.73367 & 35.81183 & 29.160 & 7 & 79 & 159 & 14 & 10 & 13 & 3.8 \\
\hline 17 & 2007 & 9 & 4 & 21 & 51 & 43.630 & -3.73133 & 35.81433 & 28.960 & 329 & 87 & 161 & 17 & 12 & 8 & 2.2 \\
\hline 18 & 2007 & 9 & 8 & 9 & 29 & 28.350 & -3.71017 & 35.85433 & 33.990 & 144 & 68 & 158 & 16 & 11 & 11 & 2.8 \\
\hline 19 & 2007 & 9 & 14 & 0 & 41 & 57.820 & -3.73150 & 35.81200 & 28.300 & 155 & 77 & -161 & 28 & 23 & 6 & 2.1 \\
\hline 20 & 2007 & 9 & 17 & 21 & 24 & 31.880 & -3.70717 & 35.81917 & 29.370 & 15 & 73 & -91 & 17 & 22 & 11 & 3.5 \\
\hline 21 & 2007 & 10 & 4 & 9 & 13 & 7.690 & -3.72917 & 35.78983 & 36.400 & 159 & 75 & 162 & 30 & 26 & 8 & 2.7 \\
\hline 22 & 2007 & 10 & 6 & 11 & 47 & 3.990 & -3.77917 & 35.78900 & 25.560 & 165 & 62 & -150 & 22 & 23 & 8 & 2.2 \\
\hline 23 & 2007 & 10 & 12 & 8 & 22 & 28.070 & -3.73083 & 35.81467 & 28.770 & 166 & 78 & -154 & 17 & 8 & 9 & 2.6 \\
\hline 24 & 2007 & 10 & 30 & 22 & 22 & 10.880 & -3.75067 & 35.66967 & 22.690 & 202 & 54 & -120 & 27 & 29 & 8 & 2.1 \\
\hline 25 & 2007 & 11 & 8 & 9 & 58 & 44.440 & -3.81100 & 35.64500 & 23.090 & 4 & 45 & -109 & 21 & 19 & 8 & 2.2 \\
\hline 26 & 2007 & 11 & 8 & 23 & 51 & 14.020 & -3.73683 & 35.70767 & 19.070 & 69 & 25 & -59 & 9 & 18 & 8 & 2.4 \\
\hline
\end{tabular}

${ }^{a}$ ID is the identification number of the focal mechanism (Figures 2 and 3). Fault plane uncertainty (FPU) is given for each nodal plane (1 and 2). Strike, dip, and rake are given for the nodal plane numbered 1 . Npol is the number of $P$ wave polarities.

Balangida fault which main direction are $\sim$ NNESSW and $\sim$ NE-SW, respectively. The events showing strike-slip mechanisms belong to two $\sim \mathrm{N} 65^{\circ} \mathrm{E}$ elongated clusters, underlined in Figure 2 (blue lines), which is the mean direction of one of their nodal planes. The depth distribution of the strike-slip focal mechanisms fits remarkably well with these vertical nodal planes (cross section A$\mathrm{A}^{\prime}$ in Figure 2), in particular for the northernmost cluster, indicating they correspond to the fault plane. The group of strike-slip focal mechanisms show that left lateral strike-slip faulting is occurring at large depth under Lake Manyara $(>20 \mathrm{~km})$ along two vertical fault planes striking $\sim \mathrm{N} 65^{\circ} \mathrm{E}$. This direction is subparallel to the Eyasi and Balangida faults and to the structural grain of the Mbulu domain [Le Gall et al., 2008] (Figure 1).

[13] Most of the normal focal mechanisms we obtained are similar with those found by Mulibo and Nyblade [2009]. Nodal planes strike $\sim \mathrm{N} 20^{\circ} \mathrm{E}$, subparallel to the main direction of the Manyara fault, indicating that the nodal plane dipping eastward is the fault plane. We also observe that some of the normal mechanisms, in particular, the southernmost ones (numbered 7, 10, 11, and 12; Figure 2 and Table 1), strike parallel to the direction of the Balangida fault and to some of the segments of the Manyara fault. This pattern supports a change in the orientation of the rift in the NTD which tends to develop along NE-SW structures located in the Tanzanian craton. In addition, the change in the morphotectonics of the rift (section 2.) is underlined by the relative location of the focal mechanisms (normal mechanisms bordering the group of strike-slip mechanisms to the west and to the east), which form a typical relay zone [e.g., Crider and Pollard, 1998].

\subsection{Local Stress Field}

[14] The inversion of the stress tensor was performed with the method of Michael [1984, 1987] using the ZMAP software [Wiemer, 2001]. Following a bootstrapping approach, numerous stress tensors are computed by randomly removing and/or duplicating the nodal planes used in the inversion whose distribution gives the area of confidence for the final tensor. We selected the nodal planes identified as the fault plane a priori in order to get the best and reliable solution [Michael, 1987]. The inversion performed without perturbing the input mechanisms gives the "best" tensor. The results of the inversion for the 26 mechanisms are the orientation of the principal stresses $\sigma 1, \sigma 2$, and $\sigma 3$ (with $\sigma 1 \geq \sigma 2 \geq \sigma 3)$, the ratio $\mathrm{R}=(\sigma 2-\sigma 3) /(\sigma 1-\sigma 3)$ 


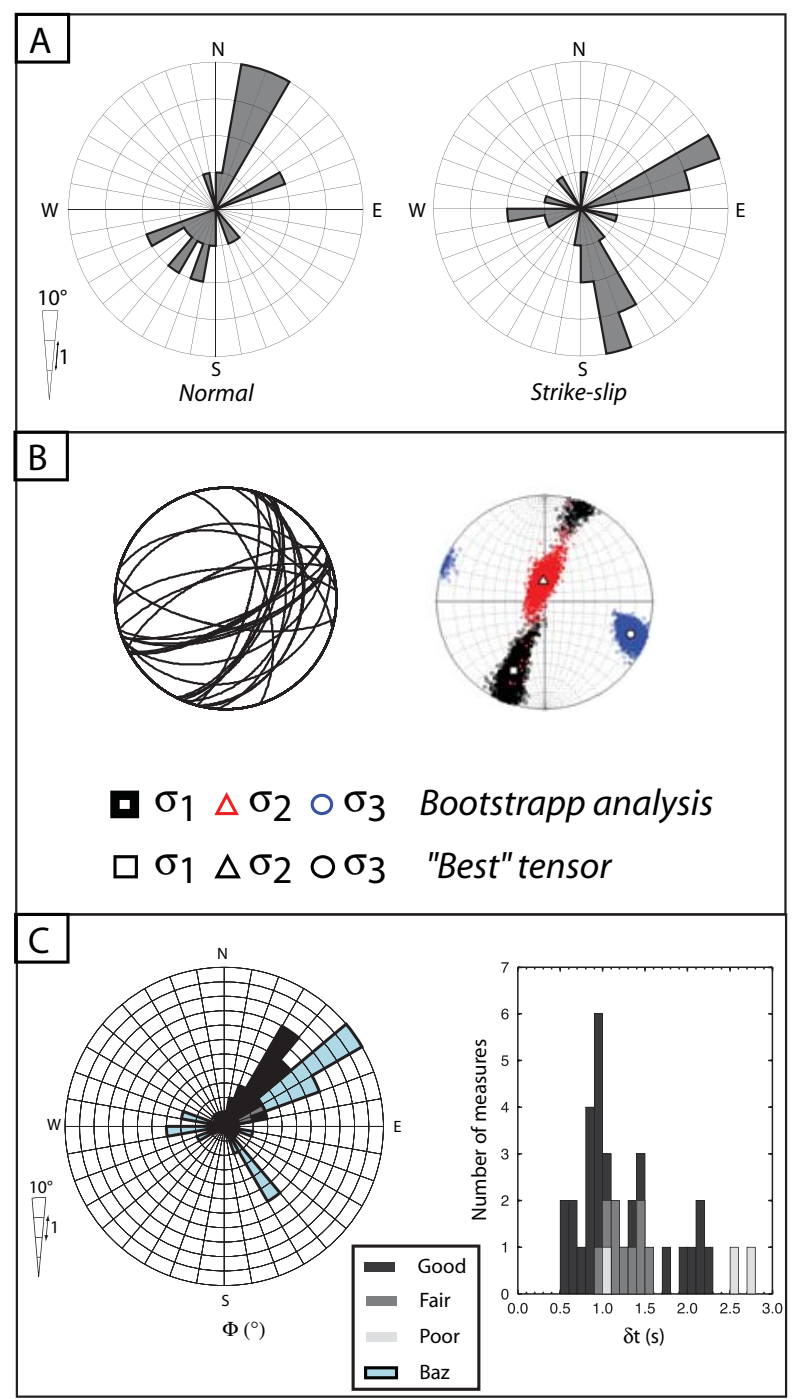

Figure 4. (a) Rose diagrams showing the direction of the nodal planes of (left) normal and (right) strike-slip focal mechanisms. (b) Nodal planes used in the (left) stress inversion and (right) associated results in term of principal stress directions. (c) Results from SKS splitting measurements: (left) direction of the fast shear wave and backazimuth of null measurements and (right) time delays. See text for details.

associated with the shape of the ellipsoid [Angelier, 1975], and the average misfit angle $\beta$ between observed and predicted slip directions (Table 2 and Figure 4b). The distribution of the different solutions around the "best" tensor gives insights into the uncertainty associated with each stress component. We obtain a strike-slip local stress tensor, with $\beta$ equal to $18^{\circ}$. The minimum principal stress $\sigma 3$ is horizontal, strikes $\mathrm{N} 110^{\circ} \mathrm{E}$ and is well constrained, according to the small area covered by all $\sigma 3$ axes. The relatively high value for $\beta$ is mainly due to the uncertainty in the maximum and inter- mediate stresses directions. Solutions for $\sigma 1$ and $\sigma 2$ are indeed distributed over larger areas, which almost overlap (Figure 4b). This observation is typical for a transtensive stress regime, which is indicated by the value of $\mathrm{R}=0.79$ [Delvaux et al., 1997].

\section{Seismic Tomography}

[15] We conducted an analysis of the 3-D $P$ and $S$ wave velocity fields in the NTD, using the local earthquake tomography method of Koulakov [2009]. The procedure includes several steps performed iteratively: (i) location of the events in the updated 3-D velocity model; (ii) construction of the parameterization grids by taking into account the ray density (performed only during the first iteration); and (iii) inversion of the derivative matrix for velocity and location parameters (coordinates and origin time). An additional matrix block is responsible for the smoothness of the $P$ and $S$ wave velocity models. Traveltime tables are computed with a modified version of the pseudobending ray tracing algorithm of Um and Thurber [1987]. The LSQR algorithm is used for the matrix inversion [Paige and Saunders, 1982]. The minimal grid nodes spacing is $2 \mathrm{~km}$. In this study, all results are shown after five iterations because the following ones do not provide significant improvement. We selected earthquakes recorded by at least four stations and with a maximal epicentral distance of $100 \mathrm{~km}$. As a whole, 2051 events were selected and all corresponding arrivals (27185 P and $26050 S$ wave arrivals) were used for the tomographic inversion. In the following, results are shown in Figures 5 and 6 for the $P$ wave velocity model and in supporting information Figures $\mathrm{S} 1$ and $\mathrm{S} 2^{1}$ for the $S$ wave velocity model. The 1$\mathrm{D}$ initial velocity model was extracted from previous studies in the area (Figure 5d) [Albaric et al., 2010, and references therein].

[16] We performed several synthetic tests, based on the real data (event distribution, number of phases, picking error), in order to check the lateral and vertical resolution of the model in different parts of the study area. To simulate picking errors, we added normal distributed random noise to the synthetic traveltimes, with average values of 0.05 and 0.1 s for $P$ and $S$ wave traveltimes, respectively. Figure 5a present the results of the

\footnotetext{
${ }^{1}$ Additional supporting information may be found in the online version of this article.
} 
Table 2. Results From the Local Stress Tensor Inversion Based on the 26 Focal Mechanisms Determined at Manyara ${ }^{\mathrm{a}}$

\begin{tabular}{|c|c|c|c|c|c|c|c|c|}
\hline \multicolumn{2}{|c|}{$\sigma_{1}$} & \multicolumn{2}{|c|}{$\sigma_{2}$} & \multicolumn{2}{|c|}{$\sigma_{3}$} & \multirow[b]{2}{*}{ Variance } & \multirow[b]{2}{*}{$\mathrm{R}$} & \multirow[b]{2}{*}{$\beta\left(^{\circ}\right)$} \\
\hline S. $\left({ }^{\circ}\right)$ & D. $\left({ }^{\circ}\right)$ & S. $\left({ }^{\circ}\right)$ & D. $\left({ }^{\circ}\right)$ & S. $\left({ }^{\circ}\right)$ & D. $\left(^{\circ}\right)$ & & & \\
\hline-156.1 & 20.2 & -3.1 & 67.6 & 110.3 & 9.3 & 0.070 & $0.79 \pm 0.065$ & $18.39 \pm 11.95$ \\
\hline
\end{tabular}

${ }^{\mathrm{a}} \mathrm{S} .$, strike; D., dip; R, shape ratio; and $\beta$, average misfit angle.

checkerboard test with $30 \times 30 \mathrm{~km}^{2}$ horizontal cell size, built with $\pm 5 \%$ from the initial 1 -D $P$ velocity model ( $\pm 7 \%$ for $S$ velocity model, Figure S1A). The shape of the anomaly remains unchanged down to a depth of $100 \mathrm{~km}$. The best resolution is achieved in the western part of the study area between and beneath Lakes Eyasi and Manyara. Another test (Figures 5b and S1B) indicates that a free shaped velocity anomaly can be relatively well reconstructed in this area. The anomaly in the northern part of the area is only slightly recovered beneath the Meru region and strong smearing is observed elsewhere. The depth resolution is tested with a vertical checkerboard, oriented N-S (Figures 5c and S1C). The sign change of the anomalies at $20 \mathrm{~km}$ depth is not detected, indicating that the velocity model is vertically poorly resolved. This test illustrates the limitation of results we can get from the seismic tomography using this data set. This is mainly due to the uneven distribution of the earthquakes into two main clusters in the Manyara and Natron regions, resulting in an uneven distribution of the seismic rays within the crust. From the synthetic tests, we conclude the 3 -D velocity model can only be constrained laterally and mainly in the Eyasi-Mbulu-Manyara region.

[17] Results of the tomographic inversion using the real data are presented in Figures 6 and S2 for $P$ and $S$ waves, respectively (horizontal and vertical sections). After five iterations, the average residuals decrease from 0.129 to $0.082 \mathrm{~s}(36.2 \%)$ for $P$-traveltimes and from 0.253 to $0.142 \mathrm{~s}$ (43.9\%) for $S$-traveltimes. $P$ and $S$ velocity anomalies exhibit the same patterns at all depth within the crust. Several low-velocity anomalies are observed, especially the intense and large one in the eastern part of the study area, beneath the Meru volcano. A low-velocity anomaly is also found beneath the northern part of the Mbulu domain, which extends southward in two branches below Lakes Eyasi and Manyara. Mean changes between initial and final earthquake locations are $2.2,1.0$, and $5.5 \mathrm{~km}$ in latitude, longitude, and depth, respectively, and only $0.6,0.4$, and $0.8 \mathrm{~km}$ in the SW (Eyai-Mbulu-Manyara region), reflect- ing the stability of the results in this region, where the network coverage is better (Figure 1).

[18] Although the depth resolution of our 3-D velocity model is too poor to assess the precise geometry and magnitude of the anomalies, our results are consistent with the surface geology of the NTD (lower velocities below rifted basins and volcanoes) and with previous tomographic models imaging greater depths. Indeed, a west-dipping low-velocity zone is imaged down to 300-400 km depth beneath the eastern branch of the EARS [Nyblade et al., 2000; Hansen et al., 2012; Mulibo and Nyblade, 2013a]. From the analysis of receiver functions, a mantle plume connected to the African superplume is assumed to drive a thermal anomaly of $\sim 200-300 \mathrm{~K}$ upward besides the Tanzanian craton [Huerta et al., 2009; Mulibo and Nyblade, 2013b]. A recent surface wave tomography analysis by O'Donnell et al. [2013] provides evidence for a wide low-velocity region in eastern Tanzania, with a broad anomaly (over ca. 200-300 km) in the uppermost mantle below Kilimanjaro-Manyara areas which remains relatively weak compared to north Malawi, Kivu, or Kenya rift anomalies. According to our results, this thermal perturbation reported in the upper mantle would, therefore, extend within the crust along the rifted basins (Eyasi and Manyara in particular). In addition, the almost absence of surface volcanic activity along these basins as well as the relatively low surface heat flow measured in the area $(46 \mathrm{~mW} /$ $\mathrm{m}^{2}$ ) [Nyblade et al., 1990] suggest that the crust is thermally perturbed at relatively large depth. Other low-velocity anomalies are observed beneath the Ngorongoro crater, south of the Kenya rift (Lake Natron area) and in the southern end of the NTD. However, the reliability and accuracy of the results are more limited in these areas since they are located outside the seismic network.

\section{Seismic Anisotropy}

[19] We used shear wave splitting measurements in order to characterize the seismic anisotropy and investigate the upper mantle strain field beneath the NTD. Seismic anisotropy in the upper mantle 
A
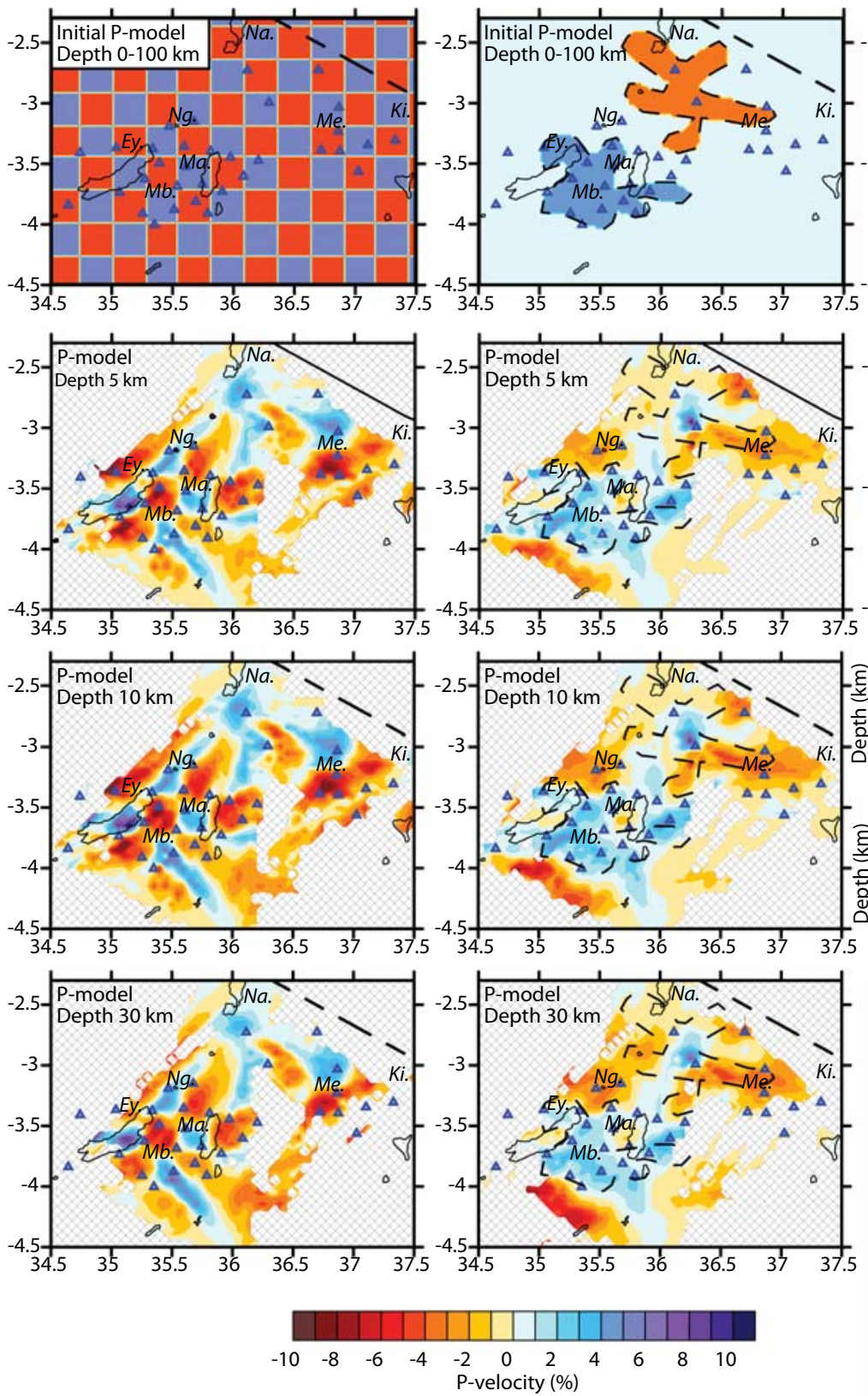

\section{C}
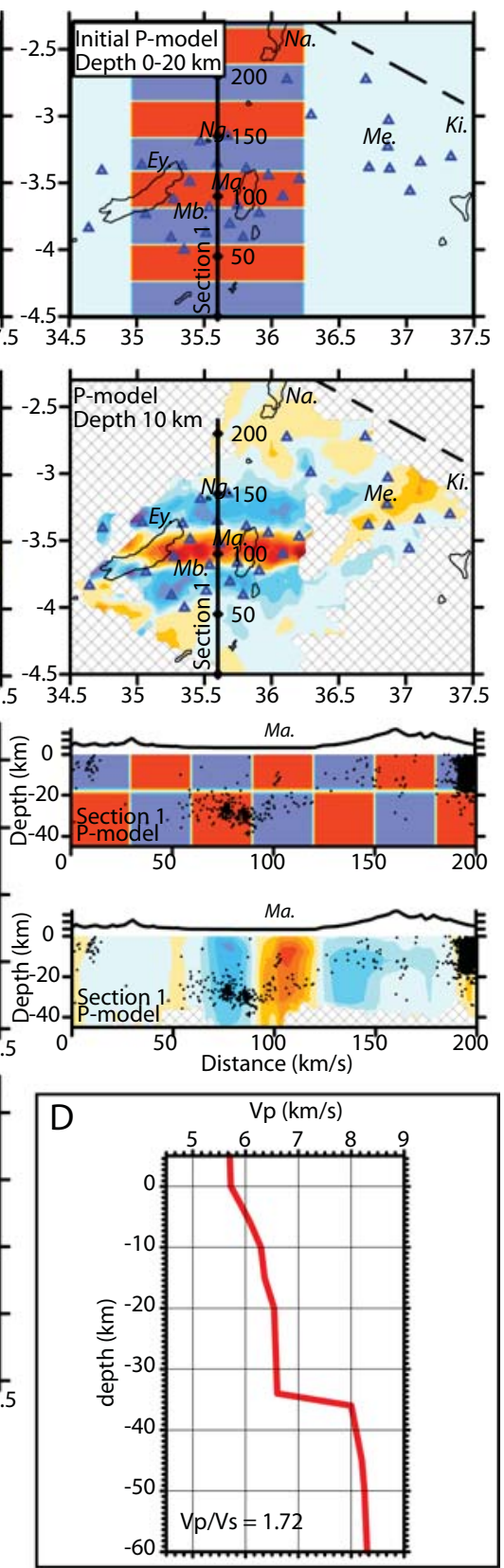

Figure 5. Synthetic tests for seismic tomography ( $P$ wave velocity). (a) Lateral checkerboard test $( \pm 5 \%$ from initial velocity model). From top to bottom: initial synthetic velocity model, slices at 5,10 , and $30 \mathrm{~km}$ depth into recovered velocity model. (b) Lateral free shape anomaly ( $\pm 4 \%$ from initial velocity model). From top to bottom: synthetic model, slices at 5, 10, and $30 \mathrm{~km}$ depth into recovered velocity model. (c) Vertical checkerboard test along a N-S profile (section 1.). From top to bottom: map view of the synthetic model (between 0 and $20 \mathrm{~km}$ depth), recovered anomaly at $10 \mathrm{~km}$ depth, cross section in the synthetic model, recovered anomaly. (d) Initial 1-D velocity model. Blue triangles correspond to the seismic stations. Ey., Eyasi; Ki., Kilimanjaro; Ma., Manyara; Me., Meru; Mb., Mbulu; and Ng., Ngorongoro.

is dominated by the lattice-preferred orientation (LPO) of olivine and orthopyroxene crystals which develops during the plastic deformation of the mantle [Ben Ismaïl and Mainprice, 1998; Nicolas and Christensen, 1987].
[20] While passing through an anisotropic region, an incident shear wave splits into two orthogonally polarized shear waves, propagating at different speed (analogous to optical birefringence) [e.g., Christensen, 1966]. The polarization direction of 


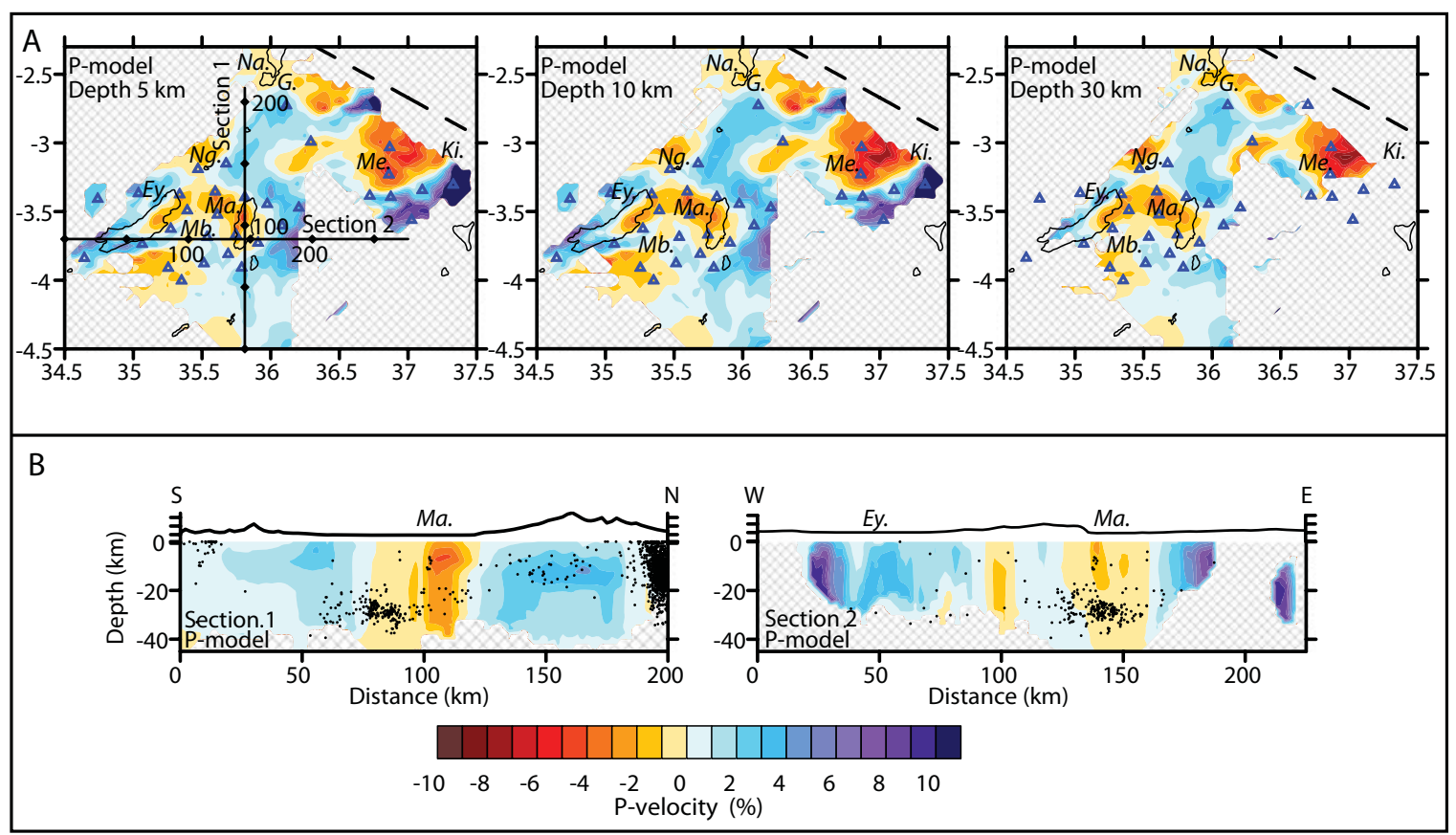

Figure 6. Results from the local earthquake tomography (3-D $P$ wave velocity). (a) Map views of the velocity model (from left to right: slices at 5,10 , and $30 \mathrm{~km}$ depth). (b) Vertical sections into the velocity model cutting through the Manyara cluster (see map in a, top left corner). Blue triangles correspond to the seismic stations. Ey., Eyasi; G., Gelai; Ki., Kilimanjaro; Ma., Manyara; Me., Meru; Mb., Mbulu; and Ng., Ngorongoro.

the faster split wave $(\Phi)$ and the time delay $(\delta \mathrm{t})$ between the two waves can be measured from three-component seismic recordings at the surface and used to quantify the effect of anisotropy. The first splitting parameter $\Phi$ provides information on the direction of flow, and the second one, $\delta \mathrm{t}$, on the depth extent and magnitude of the anisotropy.

[21] Teleseismic shear waves such as SKS, PKS, or SKKS are particularly well adapted to study shear wave splitting. They propagate through the liquid outer core as compressive waves and convert again into shear waves, radially polarized, at the coremantle boundary (CMB). Therefore, they record the anisotropy lying between the CMB and the surface. In addition, petrophysical [e.g., Ben-Ismail et al., 2001; Mainprice and Silver, 1993; Meade et al., 1995] and seismological [McNamara et al., 1994; Silver, 1996; Sieminski et al., 2007] studies suggest that SKS phases are mostly sensitive to anisotropy located in the uppermost $400 \mathrm{~km}$ of the Earth. The anisotropy measured through shear wave splitting can then be related to ongoing or fossil upper mantle flow [Silver and Chan, 1988].

[22] We analyzed shear wave splitting of teleseismic waveforms recorded by our seismic network in Tanzania. We selected 212 events in the
National Earthquake Information Center database (NEIC, http://earthquake.usgs.gov/earthquakes/ eqarchives/epic/) according to their magnitude $\left(\mathrm{M}_{\mathrm{w}} \geq 5.6\right)$ and epicentral distance $\left(85^{\circ} \leq \Delta \leq 130^{\circ}\right)$. They originated mainly from the western side of the Pacific plate (from the Japan trench to the north to the Alpine fault to the south) and from the Lesser Antilles subduction zone and the PeruChile trench (Table 3). We used the code Splitlab [Wüstefeld et al., 2008] to process the data. Synthetic traveltimes were computed using the Earth model IASP91 [Kennett and Engdahl, 1991]. We applied the eigenvalue method [Silver and Chan, 1991] in order to determine $\Phi$ and $\delta$ t that best remove the effect of splitting, that is allowing to linearize the particle motion in the radial (Q) - transverse (T) plane. We also crosschecked the results by applying the minimum energy method [Silver and Chan, 1991], which consists in minimizing the energy on the transverse component. Waveforms were band-pass filtered, generally between 0.01 and $0.5 \mathrm{~Hz}$, and a quality was assigned to each measurement (good, fair, or poor), following the criterion of Barruol et al. [1997]. If no anisotropy is detected, the measurement is considered as a "null." A null indicates either the absence of anisotropy under the station 
Table 3. Individual Splitting Parameters Obtained at Each Station From 25 Teleseismic Events ${ }^{\mathrm{a}}$

\begin{tabular}{|c|c|c|c|c|c|c|c|c|c|}
\hline Sta & Time & Lat $\left(^{\circ}\right)$ & Lon $\left(^{\circ}\right)$ & $\operatorname{Baz}\left({ }^{\circ}\right)$ & $\Phi\left(^{\circ}\right)$ & $\sigma_{\Phi}\left(^{\circ}\right)$ & $\delta \mathrm{t}(\mathrm{s})$ & $\sigma_{\delta \mathrm{t}}(\mathrm{s})$ & Q \\
\hline $\mathrm{AICH}$ & 2007.271 & -21.26 & 169.44 & 121.00 & -47.50 & 20.00 & 1.34 & 0.58 & Fair \\
\hline $\mathrm{AICH}$ & 2007.273 & -49.41 & 163.26 & 146.70 & Null & Null & Null & Null & GoodNull \\
\hline $\mathrm{AICH}$ & 2007.273 & -49.42 & 163.95 & 146.97 & Null & Null & Null & Null & FairNull \\
\hline $\mathrm{AICH}$ & 2007.197 & 36.80 & 134.87 & 53.28 & Null & Null & Null & Null & GoodNull \\
\hline $\mathrm{AICH}$ & 2007.320 & -2.31 & -77.84 & 265.90 & 31.03 & 13.50 & 1.28 & 0.29 & Fair \\
\hline $\mathrm{AICH}$ & 2007.271 & 21.99 & 142.68 & 68.11 & Null & Null & Null & Null & GoodNull \\
\hline BASH & 2007.197 & 37.57 & 138.39 & 52.35 & Null & Null & Null & Null & GoodNull \\
\hline BASH & 2007.197 & 36.80 & 134.87 & 53.31 & 70.92 & 23.00 & 1.02 & 0.52 & Fair \\
\hline $\mathrm{COFF}$ & 2007.197 & 36.80 & 134.87 & 53.28 & 44.57 & 3.00 & 1.98 & 0.44 & Good \\
\hline $\mathrm{COFF}$ & 2007.197 & 37.57 & 138.39 & 52.35 & Null & Null & Null & Null & GoodNull \\
\hline ENDA & 2007.207 & 2.82 & 127.48 & 87.31 & 13.31 & 15.50 & 0.90 & 0.42 & Good \\
\hline ENDA & 2007.197 & 36.80 & 134.87 & 53.23 & 69.23 & 20.50 & 1.15 & 0.52 & Fair \\
\hline ENDA & 2007.249 & 24.33 & 122.25 & 65.53 & Null & Null & Null & Null & GoodNull \\
\hline ENDA & 2007.197 & 37.57 & 138.39 & 52.24 & 60.24 & 21.00 & 1.47 & 0.98 & Fair \\
\hline ENDA & 2007.232 & 6.13 & 127.38 & 84.00 & 76.00 & 6.50 & 1.47 & 0.35 & Good \\
\hline ENDA & 2007.215 & -62.88 & 145.44 & 154.51 & -36.50 & 21.50 & 2.50 & 0.84 & Poor \\
\hline MOSH & 2007.318 & -22.25 & -69.89 & 245.99 & 49.45 & 19.00 & 1.34 & 0.61 & Good \\
\hline MOSH & 2007.271 & 21.99 & 142.68 & 68.09 & Null & Null & Null & Null & FairNull \\
\hline MOSH & 2007.304 & 18.90 & 145.36 & 71.19 & Null & Null & Null & Null & GoodNull \\
\hline MOSH & 2007.273 & -49.42 & 163.95 & 146.22 & Null & Null & Null & Null & GoodNull \\
\hline MOSH & 2007.197 & 36.80 & 134.87 & 53.29 & Null & Null & Null & Null & GoodNull \\
\hline MOSH & 2007.197 & 37.57 & 138.39 & 52.36 & Null & Null & Null & Null & GoodNull \\
\hline MOSH & 2007.215 & -62.88 & 145.44 & 154.21 & Null & Null & Null & Null & FairNull \\
\hline MOSH & 2007.202 & -22.20 & -65.83 & 246.64 & 56.13 & 23.50 & 2.11 & 0.85 & Good \\
\hline LGDO & 2007.318 & -22.25 & -69.89 & 246.22 & Null & Null & Null & Null & GoodNull \\
\hline LGDO & 2007.271 & 21.99 & 142.68 & 67.90 & 11.01 & 22.50 & 0.64 & 0.96 & Good \\
\hline LGDO & 2007.273 & -49.42 & 163.95 & 146.33 & -15.18 & 15.00 & 1.76 & 0.71 & Good \\
\hline LGDO & 2007.304 & 18.90 & 145.36 & 70.97 & Null & Null & Null & Null & GoodNull \\
\hline LGDO & 2007.197 & 36.80 & 134.87 & 53.20 & 38.20 & 20.00 & 0.80 & 0.58 & Good \\
\hline LGDO & 2007.320 & -2.31 & -77.84 & 266.22 & Null & Null & Null & Null & GoodNull \\
\hline LGDO & 2007.288 & -44.75 & 167.49 & 143.45 & 25.82 & 32.50 & 1.12 & 0.33 & Good \\
\hline LGDO & 2007.319 & -22.92 & -70.24 & 245.49 & Null & Null & Null & Null & FairNull \\
\hline LGDO & 2007.273 & -49.41 & 163.26 & 146.07 & -1.17 & 26.25 & 0.80 & 0.54 & Good \\
\hline LGDO & 2007.197 & 37.57 & 138.39 & 52.23 & Null & Null & Null & Null & GoodNull \\
\hline MARN & 2007.207 & 2.82 & 127.48 & 87.32 & 23.97 & 28.50 & 1.28 & 0.45 & Good \\
\hline MARN & 2007.197 & 36.80 & 134.87 & 53.26 & 71.67 & 17.00 & 1.54 & 0.58 & Fair \\
\hline MARN & 2007.197 & 37.57 & 138.39 & 52.28 & 74.14 & Inf & 1.02 & Inf & Poor \\
\hline MARN & 2007.179 & -7.97 & 154.63 & 101.08 & Null & Null & Null & Null & FairNull \\
\hline MGWE & 2007.197 & 37.57 & 138.39 & 52.36 & Null & Null & Null & Null & GoodNull \\
\hline MKAO & 2007.207 & 2.82 & 127.48 & 87.34 & 53.34 & 7.50 & 0.96 & 0.11 & Good \\
\hline MLLA & 2007.319 & -22.79 & -70.19 & 245.48 & 3.56 & 22.00 & 0.83 & 0.95 & Good \\
\hline MLLA & 2007.320 & -2.31 & -77.84 & 265.98 & Null & Null & Null & Null & FairNull \\
\hline MWAB & 2007.320 & -2.31 & -77.84 & 265.92 & Null & Null & Null & Null & GoodNull \\
\hline MWAB & 2007.232 & 6.13 & 127.38 & 84.06 & 48.09 & 15.00 & 0.90 & 0.26 & Good \\
\hline MWAB & 2007.271 & 21.99 & 142.68 & 68.10 & Null & Null & Null & Null & GoodNull \\
\hline MWAB & 2007.273 & -49.41 & 163.26 & 147.07 & -82.50 & 27.50 & 1.02 & 0.39 & Fair \\
\hline NAIT & 2007.271 & 21.99 & 142.68 & 68.11 & 33.76 & 22.00 & 0.58 & 0.81 & Good \\
\hline NAIT & 2007.273 & -49.42 & 163.95 & 146.74 & 33.64 & 34.00 & 2.18 & 0.56 & Good \\
\hline NAIT & 2007.245 & -11.61 & 165.76 & 107.67 & Null & Null & Null & Null & FairNull \\
\hline NAIT & 2007.304 & 18.90 & 145.36 & 71.22 & Null & Null & Null & Null & FairNull \\
\hline NAIT & 2007.197 & 36.80 & 134.87 & 53.29 & Null & Null & Null & Null & GoodNull \\
\hline NAIT & 2007.320 & -2.31 & -77.84 & 265.89 & Null & Null & Null & Null & GoodNull \\
\hline NAIT & 2007.197 & 37.57 & 138.39 & 52.33 & Null & Null & Null & Null & GoodNull \\
\hline NAIT & 2007.232 & 6.13 & 127.38 & 83.96 & Null & Null & Null & Null & GoodNull \\
\hline NAIT & 2007.202 & -22.20 & -65.83 & 246.76 & Null & Null & Null & Null & GoodNull \\
\hline NAIT & 2007.214 & 47.18 & 141.77 & 42.25 & Null & Null & Null & Null & FairNull \\
\hline NAIT & 2007.215 & -62.88 & 145.44 & 154.40 & -11.27 & 18.00 & 1.47 & 0.77 & Fair \\
\hline NAIT & 2007.179 & -7.97 & 154.63 & 100.94 & Null & Null & Null & Null & GoodNull \\
\hline NGRE & 2007.271 & 21.99 & 142.68 & 67.99 & 31.34 & 23.50 & 0.90 & 0.45 & Good \\
\hline NGRE & 2007.273 & -49.42 & 163.95 & 146.34 & 38.33 & 10.50 & 2.05 & 0.52 & Good \\
\hline NGRE & 2007.197 & 36.80 & 134.87 & 53.24 & 43.35 & Inf & 2.24 & Inf & Good \\
\hline NGRE & 2007.232 & 6.13 & 127.38 & 83.91 & 30.78 & 20.00 & 1.09 & 0.32 & Good \\
\hline NGRE & 2007.320 & -2.31 & -77.84 & 266.07 & Null & Null & Null & Null & GoodNull \\
\hline GIDA & 2007.271 & 21.99 & 142.68 & 68.10 & Null & Null & Null & Null & GoodNull \\
\hline GIDA & 2007.213 & -15.74 & 167.74 & 113.88 & 70.94 & 10.50 & 0.83 & 0.10 & Good \\
\hline GIDA & 2007.207 & 2.82 & 127.48 & 87.34 & 39.56 & 14.00 & 1.02 & 0.21 & Good \\
\hline GIDA & 2007.197 & 36.80 & 134.87 & 53.27 & Null & Null & Null & Null & FairNull \\
\hline GIDA & 2007.197 & 37.57 & 138.39 & 52.28 & Null & Null & Null & Null & FairNull \\
\hline
\end{tabular}


Table 3. (continued)

\begin{tabular}{|c|c|c|c|c|c|c|c|c|c|}
\hline Sta & Time & Lat $\left(^{\circ}\right)$ & Lon $\left(^{\circ}\right)$ & $\operatorname{Baz}\left({ }^{\circ}\right)$ & $\Phi\left({ }^{\circ}\right)$ & $\sigma_{\Phi}\left({ }^{\circ}\right)$ & $\delta \mathrm{t}(\mathrm{s})$ & $\sigma_{\delta \mathrm{t}}(\mathrm{s})$ & Q \\
\hline GIDA & 2007.232 & 6.13 & 127.38 & 84.03 & 68.87 & 15.50 & 1.09 & 0.39 & Good \\
\hline GIDA & 2007.215 & -62.88 & 145.44 & 154.56 & Null & Null & Null & Null & FairNull \\
\hline GLUM & 2007.333 & 14.97 & -61.26 & 284.76 & Null & Null & Null & Null & GoodNull \\
\hline GLUM & 2007.350 & -22.95 & -70.18 & 245.57 & 49.57 & 21.50 & 1.47 & 0.58 & Good \\
\hline KRTU & 2007.271 & 21.99 & 142.68 & 68.01 & Null & Null & Null & Null & GoodNull \\
\hline KRTU & 2007.273 & -49.42 & 163.95 & 146.88 & Null & Null & Null & Null & GoodNull \\
\hline KRTU & 2007.207 & 2.82 & 127.48 & 87.29 & 56.89 & 21.50 & 0.77 & 0.42 & Good \\
\hline KRTU & 2007.197 & 36.80 & 134.87 & 53.23 & Null & Null & Null & Null & FairNull \\
\hline KRTU & 2007.288 & -44.75 & 167.49 & 144.11 & Null & Null & Null & Null & GoodNull \\
\hline LWON & 2007.333 & 14.97 & -61.26 & 284.74 & Null & Null & Null & Null & GoodNull \\
\hline LWON & 2007.350 & -22.95 & -70.18 & 245.56 & 36.83 & 18.00 & 0.90 & 0.34 & Good \\
\hline MALJ & 2007.207 & 2.82 & 127.48 & 87.29 & 23.53 & 19.00 & 0.90 & 0.44 & Good \\
\hline MALJ & 2007.197 & 36.80 & 134.87 & 53.21 & 81.94 & 16.50 & 0.96 & 0.31 & Fair \\
\hline MONG & 2007.271 & 21.99 & 142.68 & 68.16 & Null & Null & Null & Null & GoodNull \\
\hline MONG & 2007.273 & -49.42 & 163.95 & 147.12 & Null & Null & Null & Null & GoodNull \\
\hline MONG & 2007.207 & 2.82 & 127.48 & 87.34 & 42.45 & 19.50 & 0.58 & 0.34 & Good \\
\hline MONG & 2007.197 & 36.80 & 134.87 & 53.30 & 65.14 & 22.00 & 1.34 & 0.82 & Good \\
\hline MONG & 2007.197 & 37.57 & 138.39 & 52.33 & 67.08 & 13.50 & 1.47 & 0.55 & Good \\
\hline MONG & 2007.232 & 6.13 & 127.38 & 84.02 & 67.61 & 18.50 & 1.15 & 0.52 & Fair \\
\hline MONG & 2007.231 & -20.66 & 169.70 & 120.70 & Null & Null & Null & Null & FairNull \\
\hline NOON & 2007.333 & 14.97 & -61.26 & 284.70 & Null & Null & Null & Null & GoodNull \\
\hline NOON & 2007.350 & -22.95 & -70.18 & 245.47 & 52.93 & 6.00 & 2.75 & 0.63 & Poor \\
\hline NOON & 2007.349 & -6.61 & 131.09 & 96.87 & Null & Null & Null & Null & GoodNull \\
\hline QARU & 2007.271 & 21.99 & 142.68 & 68.06 & Null & Null & Null & Null & GoodNull \\
\hline QARU & 2007.273 & -49.42 & 163.95 & 146.91 & Null & Null & Null & Null & GoodNull \\
\hline QARU & 2007.207 & 2.82 & 127.48 & 87.30 & 73.87 & 21.50 & 0.70 & 0.44 & Good \\
\hline QARU & 2007.197 & 36.80 & 134.87 & 53.26 & Null & Null & Null & Null & GoodNull \\
\hline QARU & 2007.197 & 37.57 & 138.39 & 52.28 & Null & Null & Null & Null & GoodNull \\
\hline QARU & 2007.271 & -21.26 & 169.44 & 120.85 & Null & Null & Null & Null & GoodNull \\
\hline
\end{tabular}

${ }^{\mathrm{a}}$ Sta, station; Baz, backazimuth; $\phi$, direction of the fast shear wave; $\delta$ t, time delay; $\sigma_{\phi}$ and $\sigma_{\delta \mathrm{t}}$, standard deviation of $2 \sigma$ on $\Phi$ and $\delta \mathrm{t}$ measures, respectively; Q, quality of the measurement based on the criterion from Barruol et al. [1997].

or that initial polarization azimuth of the SKS wave is parallel or perpendicular to the fast axis of the anisotropic layer. Figure 7 shows examples of good and null measurements after splitting analysis. A careful visual inspection of the data allows us to keep the results from the analysis of 97 waveforms from 25 teleseismic events. The results of individual splitting parameters are listed in Table 3. The 97 SKS or SKKS shear wave splitting measurements include 53 nulls, 31 good, 10 fair, and 3 poor.

[23] Despite the few number of measurements, we obtained consistent results between the stations. The fast anisotropy direction $\Phi$ is $\sim$ NE-SW over all the stations (between $\mathrm{N} 30^{\circ} \mathrm{E}$ and $\mathrm{N} 50^{\circ} \mathrm{E}$, Figures $4 \mathrm{c}$ and 8 ). The delay time $\delta \mathrm{t}$ is $1.19 \mathrm{~s}$ on average and increases from West to East, to more than $2 \mathrm{~s}$. Values above $2.5 \mathrm{~s}$ are observed but associated with a poor quality. The majority of the backazimuths of the nulls are subparallel or orthogonal to $\Phi$ (Figure 4c), which tends to confirm this is a dominant direction of the anisotropy. In the following, we focus on good measurements to investigate the possible origin of the anisotropy.

[24] Results from several studies in the area (Figure 8) [Gao et al., 1997; Barruol and Ben Ismail,
2001; Walker et al., 2004] and northward in the EARS (e.g., Ethiopian rift) [Kendall et al., 2006] show that the fast polarization directions beneath the rift valley are rift parallel. The authors attribute generally the measured anisotropy to the alignment of melt-filled lenses or parallel dikes beneath the rift. Our results support this interpretation, showing a similar pattern, as $\Phi$ aligns to the main rift segments within the NTD (Figure 8). In addition, this is consistent with the today's dike occurrence observed in the Lake Natron area, as $\Phi$ (e.g., GLUM and LWON stations, Figure 8) is at the same time parallel to the dike direction $\left(\sim \mathrm{N} 30^{\circ} \mathrm{E}\right)$ [Calais et al., 2008] and perpendicular to the minimum principal stress we computed $\left(\mathrm{N} 110^{\circ} \mathrm{E}\right.$, Figures $4 \mathrm{~b}$ and $4 \mathrm{~b}$ ). Fast polarization directions are often parallel to orogenic structures [e.g., Silver, 1996], in particular, in the case of mountain belts accreted to cratons [Barruol et al., 1997]. This is the case in the Mozambique belt where the origin of the anisotropy has been attributed to the $\sim \mathrm{N}-\mathrm{S}$ lithospheric fabric [Walker et al., 2004] (Figure 8). Interestingly, larger time delays are observed at the westernmost stations (e.g., LGDO, NGRE, COFF, MLLA stations) as well as more northward $\Phi$ directions. This is consistent with an increase of 

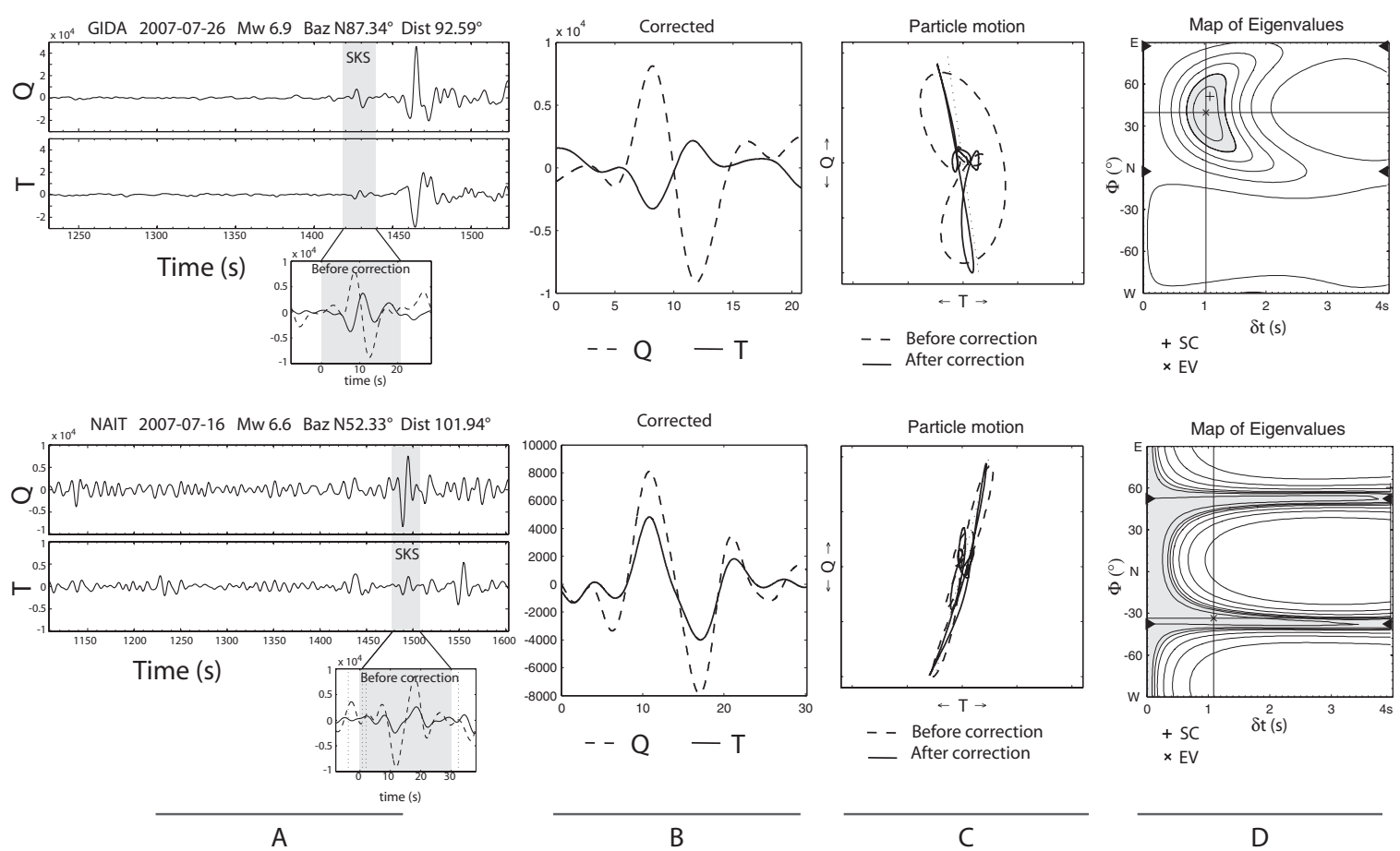

Figure 7. Example of shear wave splitting measurements at stations (top) GIDA and (bottom) NAIT.

the contribution of the fossilized anisotropy within the Proterozoic belt. Other sources of anisotropy can be invoked, such as the ductile stretching of the lithospheric mantle, which would induce the fast direction $\Phi$ to be parallel to the extension direction [Vinnik et al., 1992]. This is not the case, as $\Phi$ is oblique to the orientation of the minimum horizontal stress, globally E-W in the EARS [Delvaux and Barth, 2010; Heidbach et al., 2010]. Therefore, the hypothesis of an anisotropy due to the stretching of the lithospheric mantle is unlikely in the area, where, in addition, the present-day extension rate is very low $\left(\sim 2 \mathrm{~mm} \mathrm{yr}^{-1}\right.$ relative motion between the plates Victoria and Somalia) [Stamps et al., 2008]. Another possibility could be that the anisotropy is due to shearing of the asthenosphere, at the base of the moving plate. The related asthenospheric flow would induce $\Phi$ parallel to the absolute plate motion (APM). This hypothesis can explain the seismic anisotropy measured across the unrifted parts of the Tanzanian Craton (Figure 8) [Walker et al., 2004]. However, this is unlikely the cause of the anisotropy beneath our stations, as the APM of Africa is WNW [Gripp and Gordon, 2002], that is oblique to $\Phi$.

[25] To summarize, the results from the SKS splitting analysis suggest that the anisotropy in the NTD can be mainly related to (1) the alignment of melted lenses or parallel dikes and (2) the lithospheric fabric.

\section{Discussion}

[26] We have processed seismological data recorded in the NTD allowing us to constrain new focal mechanisms, seismic tomography, and seismic anisotropy. Our main results indicate that (1) the deeply rooted seismicity recorded at Manyara involves strike-slip and normal faulting on structures oriented NNE-SSW and NE-SW, within the craton margin; (2) a low-velocity anomaly is observed below the NTD, in particular beneath the Manyara rift, and interpreted as a thermomechanical perturbation into the crust; (3) the presence of magma-filled lenses appears to be the dominant source of anisotropy below the NTD, followed by the effect of lithospheric fabrics. In the following, we investigate the triggering mechanisms of the seismic cluster below Lake Manyara and discuss the implications of our results on the understanding of rift initiation in the NTD.

\subsection{Lower Crustal Earthquakes: Origin and Implications on the Seismogenic Deformation in the NTD}

[27] Lower crustal earthquakes have often been reported in continental rifts, especially in East Africa, below the eastern and the western branches of the EARS [Nyblade and Langston, 1995; 


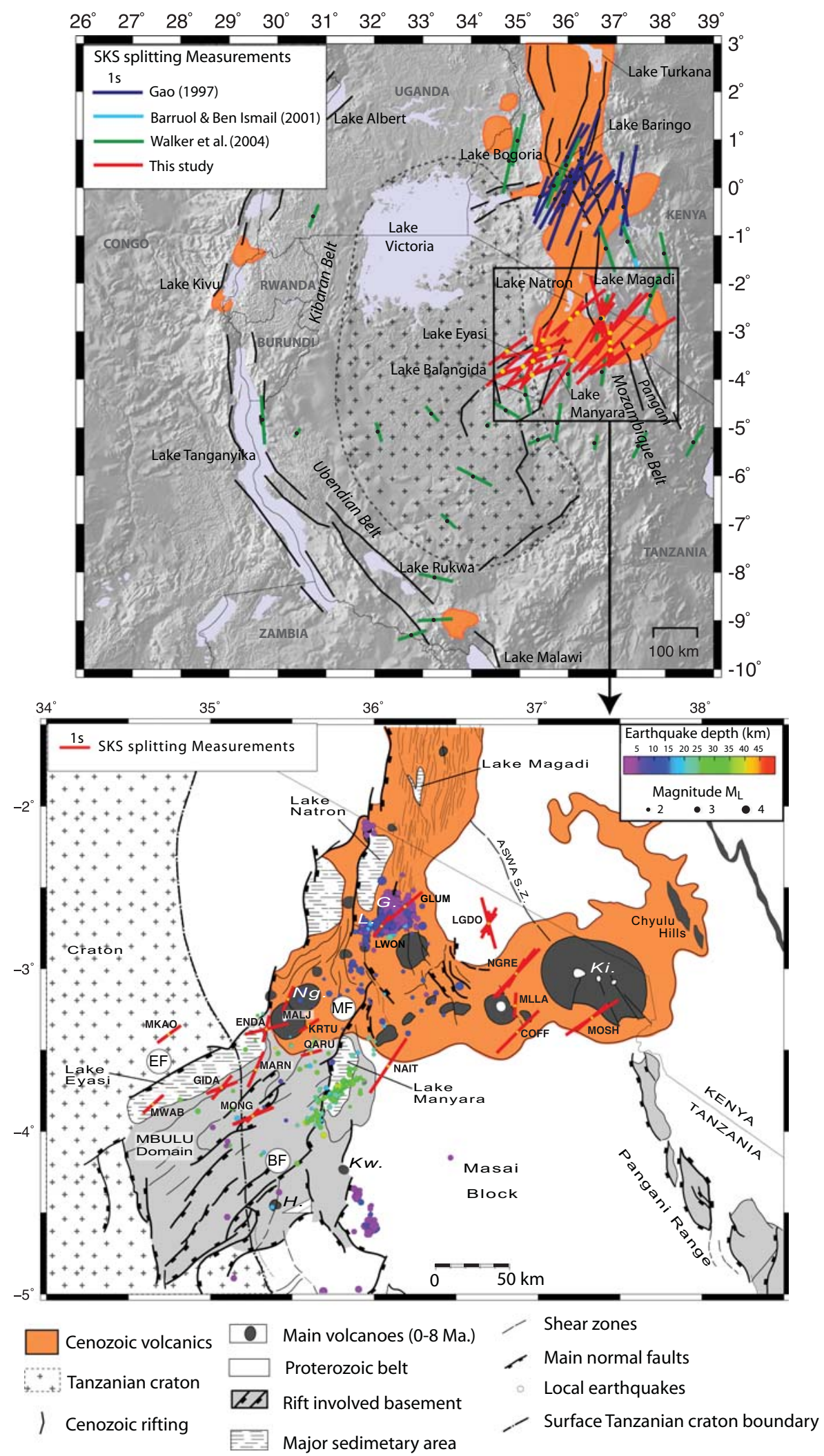

Figure 8. SKS-splitting measurements in the western and eastern branches of the EARS. The direction of the fast shear wave is indicated by a bar colored according to the study (previous and current studies), which length is proportional to the time delay. 
Camelbeeck and Iranga, 1996; Ibs-von Seht et al., 2001; Albaric et al., 2010; Lindenfeld and Rümpker, 2011] or outside the rift axis, as in Ethiopia [Keir et al., 2009]. Their occurrence can be explained by the presence of a highly resistant lithosphere, which allows increasing the depth of the brittle-to-ductile transition [Shudofsky et al., 1987; Nyblade and Langston, 1995; Albaric et al., 2009]. Indeed, in order to account for brittle failure at high temperature in the lower crust, a mafic composition is required [Kohlstedt et al., 1995]. This is likely the case in the NTD [Julia et al., 2005]. The earthquakes are even generally deeper than elsewhere in the EARS because of the presence of the cratonic lithosphere, which presents lower surface heat flow and is relatively stronger and thicker [Albaric et al., 2009, 2010].

[28] We have identified the main critically stressed structures associated with the deep earthquakes recorded beneath Lake Manyara. Focal mechanisms indicate that similarly oriented faults observed at the surface are active at large depth and form a relay zone (Figure 2). Our results evidence for the first time active strike-slip fault segments joining normal NNE-SSW faults: they involve NE-directed Archaean basement fabrics, at the contact between the Mbulu domain and the Masai cratonic block (Figure 1). In addition to be deep, the earthquakes recorded at Manyara have a swarm-like distribution [Albaric et al., 2010], which is typical in continental rifts [e.g., Ibs-von Seht et al., 2008] and for fluid-induced seismicity [Vidale and Shearer, 2006; Reyners et al., 2007; Lindenfeld et al., 2012]. The local magnitude varies between 1.8 and 3.6, which is comparable to other swarms in the EARS (e.g., Rwenzori region, $0.4 \leq \mathrm{M}_{\mathrm{L}} \leq 4$ ) [Lindenfeld et al., 2012]. Finally, the sequence has the particularity to be of long duration (recorded for several years; section 3.). Pore pressure variations related to the presence of hydrous fluids have often been invoked as a triggering mechanism of lower crustal swarms beneath continental rifts [Reyners et al., 2007; Keir et al., 2009; Lindenfeld et al., 2012]. At Manyara, the presence of fluids is suggested by the numerous thermal springs reported south of the lake [see compilation in Macheyeki et al., 2008]. The presence of magmatic sources or partial melt zones at depth could favor fluid release through, for example, the heating of hydrated rocks composing the craton [Sommer, 2009], and thus promote slip on critically oriented structures. This scenario is supported by the results from seismic tomography and seismic anisotropy, which are both consistent with the presence of magmatic bodies beneath the Manyara rift. In addition, a steady source of fluids/gases would explain how the production of seismicity is maintained over long periods of time. Other processes related to the presence of magmatic sources at depth could also generate seismicity, such as dike injections or rheological contrasts in the vicinity of melted zones. However, we think they are not dominant in producing seismicity during the period of observation. We would expect in this case some clearer signs in the spatio-temporal distribution of the events, such as an increase and decrease or cessation of the seismicity (see e.g., dike event in Natron) [Albaric et al., 2010], or additional seismic activity drawing around magma pockets [e.g., Keir et al., 2009]. Therefore, we propose that fluid overpressure arising from deeply rooted magmatism likely triggers the long-lasting and deep crustal seismicity observed.

[29] Another interesting outcome from the observation of the swarm-like seismicity recorded at Manyara and elsewhere in the EARS [Ibs-von Seht et al., 2008] concerns the seismogenic behavior of the faults involved in rifting. The seismic activity in the NTD is characterized by the frequent occurrence of earthquakes of magnitude $\mathrm{M}_{\mathrm{w}}$ 5.0-5.3 [Langston et al., 1998; Foster and Jackson, 1998]. The largest earthquakes were observed south of Lake Eyasi (07/05/1964, 05:45, mb 6.3, $31.5 \mathrm{~km}$ depth) [Engdahl et al., 1998] and in Lake Natron area (Figure 1, 17/07/2007, 14:10, $\mathrm{M}_{\mathrm{w}} 5.9,4.7 \mathrm{~km}$ depth) [Calais et al., 2008]. However, it has been shown that such events do not necessarily account for all the deformation in the region and can even contribute less than aseismic processes [Baer et al., 2008; Calais et al., 2008; Biggs et al., 2009]. Actually, the high and long-duration rate of seismicity recorded at Manyara [Nyblade et al., 1996; Albaric et al., 2010] can be interpreted as the expression of the "aseismic" behavior of some faults in the NTD (fault creep). Detailed and longterm studies of some large faults, like the San Andreas Fault, have for example revealed that seismic swarms are a good indicator for fault creep behavior [e.g., Scholz, 2002; Lohman and McGuire, 2007].

\subsection{Rift Initiation in the NTD: Influence of Magmatism and Archaean Basement Fabrics}

[30] According to our results, the development of the rift in the youngest portion of the EARS is 
greatly influenced by magmatic processes. Purely magmatic rifting models show that the presence of localized and deep magmatic activity allows reducing considerably the level of strength necessary to break the lithosphere [Buck, 2006; Bialas et al., 2010]. This is what we observe in the NTD where the locus of rifting seems to be determined by the presence of magmatism: although the lithosphere is strong and rigid in the NTD (Tanzanian craton and Masai block), the rift preferentially develops in this region, rather than in a zone of weak lithosphere (e.g., east of Lake Victoria) [see Perez-Gussinye et al., 2009]. In addition, as mentioned in the previous section, the presence of magmatism favors aseismic mechanisms (fault creep, magmatic injections), which could contribute significantly to the present-day deformation in the NTD. Note that in contrast with several other areas of the EARS, such as the Main Ethiopian Rift (MER), Afar, Natron, or Read Sea Rifts [Calais et al., 2008; Keir et al., 2011; Grandin et al., 2011; Daniels et al., 2014], the Manyara and Eyasi rifts depict ultraslow extension rates, deeper $(>20 \mathrm{~km})$ seismicity, very limited volcanism and moderate heat flow, suggesting that dike intrusion has not reached yet the same role in the accommodation of extension. Whether the gradual weakening of the lithosphere is primarily controlled by the "long-term memory" of fractured rocks [Lyakhovsky et al., 2012; Fagereng, 2013] or by "intrusional heating" [Schmeling and Wallner, 2012] at onset of rifting remains difficult to resolve and is beyond the scope of this study. Obviously, our results suggest that both factors could act jointly and, therefore, add their effects to decrease lithospheric strength.

[31] Our results also show the influence of the rheology on the morphostructure of the rift, as pointed out by several studies in the NTD [Dawson et al., 1992; Ebinger et al., 1997; Foster et al., 1997; Le Gall et al., 2008]. Ebinger et al. [1997] suggest for instance that the change in the direction of the Cenozoic faults, from N-S to NE-SW, marks the buried contact between the craton and the Proterozoic belt (Figure 1). Le Gall et al. [2008] attribute the complex relay fault system connecting the Manyara and Balangida faults to a greater influence of reactivated basement structures. Our results support the latter views, explaining both the coexistence of strike-slip and normal fault plane solutions below Manyara and the similar segmented pattern of the Manyara main fault scarp (Figures 2 and 4). Results from stress field inversion also emphasize the impact of the Tanzanian craton on the today's propagation and geometry of the rift in the NTD: we find that the minimum principal stress in the NTD is horizontal and oriented $\mathrm{N} 110^{\circ} \mathrm{E}$, a strike consistent with the mean E-W direction of the minimum horizontal stress in the eastern branch of the EARS [Delvaux and Barth, 2010]. However, the local stress regime is varying from normal in south Kenya [Ibs-von Seht et al., 2001] to transtensive in the Lake Manyara area (this study), and to normal, south of the NTD [Delvaux and Barth, 2010], a pattern which is classically thought to reflect both the influence of intrusions at depth [Keir et al., 2011] and of inherited structural heterogeneities of the basement at a regional (ca. $100 \mathrm{~km}$ ) scale [Delvaux and Barth, 2010]. Our results suggest that the local stress regime could change at spatial scales of less than $10 \mathrm{~km}$ (Figure 2 ), in a way similar to the two-order segmentation pattern of the Manyara fault scarp [Le Gall et al., 2008]. Such "tortuous" fault pattern is favored when pre-existing pervasive fabrics is at $\sim 45^{\circ}$ from the stretching direction [Chattopadhyay and Chakra, 2013], which is indeed the case in the NTD.

\section{Conclusion}

[32] In this study, we provide new constraints on the relationship between tectonic and magmatic processes in North Tanzania, a place where the rift propagates slowly within Precambrian shields. Our results indicate that magmatism at the base of the Archaean crust likely induces local stress changes through different mechanisms such as fluid release and subsequent overpressures, which promotes swarm-like seismic activity on nearby pre-existing structures. We speculate that aseismic processes in the lower crust favor rift propagation within the Tanzanian craton. Besides magmatism, which determines the locus of the incipient rift, the crustal fabrics control its morphotectonic (geometry and orientation) evolution.

[33] Our results are in agreement with a rifting model in between purely magmatic [Buck, 2006] and purely mechanical [e.g., Corti, 2009]. In line with results of numerical models of lithospheric weakening and rift propagation [e.g., Lyakhovsky et al., 2012; Schmeling and Wallner, 2012], we suggest that rift initiation and propagation in north Tanzania is made possible through three main mechanisms linked to each other: (1) melt resulting from a large-scale asthenospheric thermal anomaly of $\sim 250 \mathrm{~K}$ induces a significant lithospheric weakening; (2) in a feedback mechanism, 
viscous weakening enhances the rifting process and melt production: magmatism localizes the rifting and facilitates faulting and creeping at relatively large depth $(25-30 \mathrm{~km})$ in a strong and thick crust; and (3) deep fluid pressure arising from melts promote frictional brittle failure on inherited structures of the lower crust.

\section{Acknowledgments}

[34] We are indebted to all people in Tanzania who made the SEISMO'TANZ experiment possible, and especially to Richard Wambura-Ferdinand, Evelyne M'Bede and Majura Songo (Dar-Es-Salaam University). We thank Guilhem Barruol, Stephan Husen, Bernard Le Gall, Christian Sue, Christel Tiberi, and Alain Vauchez for many helpful discussions in the course of this study. We thank two anonymous reviewers for their constructive comments. The INSU (CNRS, France) Program DYETI partly funded this project.

\section{References}

Aki, K. (1965), Maximum likelihood estimate of $b$ in the formula $\log \mathrm{N}=\mathrm{a}-\mathrm{bM}$ and its confidence limits, Bull. Earthquake Res. Inst. Univ. Tokyo, 43, 237-239.

Albaric, J., J. Déverchère, C. Petit, J. Perrot, and B. Le Gall (2009), Crustal rheology and depth distribution of earthquakes: Insights from the central and southern East African Rift System, Tectonophysics, 468, 28-41.

Albaric, J., J. Perrot, J. Déverchère, A. Deschamps, B. Le Gall, R. W. Ferdinand, C. Petit, C. Tiberi, C. Sue, and M. Songo (2010), Contrasted seismogenic and rheological behaviours from shallow and deep earthquake sequences in the North Tanzanian Divergence, East Africa, J. Afr. Earth Sci., 58, 799-811.

Angelier, J. (1975), Sur l'analyse de mesures recueillies dans des sites faillés: L'utilité d'une confrontation entre les méthodes dynamiques et cinématiques, C. R. Acad. Sci., Paris D, 281, 1805-1808.

Baer, G., Y. Hamiel, G. Shamir, and R. Nof (2008), Evolution of a magma-driven earthquake swarm and triggering of the nearby Oldoinyo Lengai eruption, as resolved by InSAR, ground observations and elastic modeling, East African Rift, 2007, Earth Planet. Sci. Lett., 272, 339-352.

Barruol, G., and W. Ben Ismail (2001), Upper mantle anisotropy beneath the African IRIS and Geoscope stations, Geophys. J. Int., 146(2), 549-561.

Barruol, G., P. G. Silver, and A. Vauchez (1997), Seismic anisotropy in the eastern United States: Deep structure of a complex continental plate, J. Geophys. Res., 102, 83298348.

Ben Ismaïl, W., and D. Mainprice (1998), An olivine fabric database: An overview of upper mantle fabrics and seismic anisotropy, Tectonophysics, 296, 145-157.

Ben-Ismail, W., G. Barruol, and D. Mainprice (2001), The Kaapvaal craton seismic anisotropy: Petrophysical analyses of upper mantle kimberlite nodules, Geophys. Res. Lett., 28, 2497-2500

Bialas, R. W., W. R. Buck, and R. Qin (2010), How much magma is required to rift a continent? Earth Planet. Sci. Lett., 292, 68-78.
Biggs, J., F. Amelung, N. Gourmelen, T. H. Dixon, and S.-W. Kim (2009), InSAR observations of 2007 Tanzania rifting episode reveal mixed fault and dyke extension in an immature continental rift, Geophys. J. Int., 179, 549-558.

Birt, C. S., P. K. H. Maguire, M. A. Khan, H. Thybo, G. R. Keller, and J. Patel (1997), The influence of pre-existing structures on the evolution of the southern Kenya Rift Valley-Evidence from seismic and gravity studies, Tectonophysics, 278(1-4), 211-242.

Buck, W. R. (2006), The role of magma in the development of the Afro-Arabian Rift System, Geol. Soc. Spec. Publ., 259, 43-54.

Bungum, H., and A. A. Nnko (1984), Seismicity and tectonics of the Stiegler's Gorge area, Tanzania, J. Geophys. Res., 89, 1874-1889.

Burke, K. (1996), The African plate, S. Afr. J. Geol., 99, 341-410.

Calais, E., C. Ebinger, C. Hartnady, and J. M. Nocquet (2006), Kinematics of the East African Rift from GPS and earthquake slip vector data, Geol. Soc. Spec. Publ., 259, 9-22.

Calais, E., et al. (2008), Strain accommodation by slow slip and dyking in a youthful continental rift, East Africa, Nature, 456, 783-787.

Camelbeeck, T., and M. D. Iranga (1996), Deep crustal earthquakes and active faults along the Rukwa trough, eastern Africa, Geophys. J. Int., 124, 612-630.

Chattopadhyay, A., and M. Chakra (2013), Influence of preexisting pervasive fabrics on fault patterns during orthogonal and oblique rifting: An experimental approach, Mar. Pet. Geol., 39(1), 74-91.

Christensen, N. I. (1966), Shear wave velocities in metamorphic rocks at pressures to 10 kilobars, J. Geophys. Res., 71, 3549-3556.

Corti, G. (2009), Continental rift evolution: From rift initiation to incipient break-up in the Main Ethiopian Rift, East Africa, Earth Sci. Rev., 96, 1-53.

Crider, J. G., and D. D. Pollard (1998), Fault linkage: Threedimensional mechanical interaction between echelon normal faults, J. Geophys. Res., 103, 24,373-24,391.

Daniels, K. A., I. D. Bastow, D. Keir, R. S. J. Sparks, and T. Menand (2014), Thermal models of dyke intrusion during development of continent-ocean transition, Earth Planet. Sci. Lett., 385, 145-153.

Dawson, J. B. (1992), Neogene tectonics and volcanicity in the North Tanzania sector of the Gregory Rift Valley: Contrasts with the Kenya sector, Tectonophysics, 204, 81-83.

Delvaux, D., and A. Barth (2010), African stress pattern from formal inversion of focal mechanism data, Tectonophysics, 482, 105-128.

Delvaux, D., R. Moeys, G. Stapel, C. Petit, K. Levi, A. Miroshnichenko, V. Ruzhich, and V. San'kov (1997), Paleostress reconstructions and geodynamics of the Baikal region, Central Asia, Part 2. Cenozoic rifting, Tectonophysics, 282, 1-38.

Déverchère, J., C. Petit, N. Gileva, N. Radziminovitch, V. Melnikova, and V. San'kov (2001), Depth distribution of earthquakes in the Baikal rift system and its implications for the rheology of the lithosphere, Geophys. J. Int., 146(3), 714-730.

Ebinger, C., and N. H. Sleep (1998), Cenozoic magmatism in central and east Africa resulting from impact of one large plume, Nature, 395, 788-791.

Ebinger, C., Y. P. Djomani, E. Mbede, A. Foster, and J. B. Dawson (1997), Rifting Archaean lithosphere: The EyasiManyara-Natron rifts, East Africa, J. Geol. Soc. London, 154(6), 947-960.

Ebinger, C., J. A. Jackson, A. N. Foster, and N. J. Hayward (1999), Extensional basin geometry and the elastic lithosphere, Philos. Trans. R. Soc. London A, 357, 741-765. 
Engdahl, E. R., R. D. Van der Hilst, and R. P. Buland (1998), Global teleseismic earthquake relocation with improved travel times and procedures for depth determination, Bull. Seismol. Soc. Am., 88(3), 722-743.

Fagereng, A. (2013), Fault segmentation, deep rift earthquakes and crustal rheology: Insights from the 2009 Karonga sequence and seismicity in the Rukwa-Malawi rift zone, Tectonophysics, 601, 216-225.

Foster, A. N., and J. A. Jackson (1998), Source parameters of large African earthquakes: Implications for crustal rheology and regional kinematics, Geophys. J. Int., 134, 422-448.

Foster, A. N., C. J. Ebinger, E. Mbede, and D. Rex (1997), Tectonic development of the northern Tanzanian sector of the East African Rift System, J. Geol. Soc. London, 154, 689-700.

Gao, S., P. M. Davis, H. Liu, P. D. Slack, A. W. Rigor, Y. A. Zorin, V. V. Mordvinova, V. M. Kozhevnikov, and N. A. Logatchev (1997), SKS splitting beneath continental rift zones, J. Geophys. Res., 102, 22,781-22,797.

George, R., N. Rogers, and S. Kelley (1998), Earliest magmatism in Ethiopia: Evidence for two mantle plumes in one flood basalt province, Geology, 26, 923-926.

Grandin, R., E. Jacques, A. Nercessian, A. Ayele, C. Doubre, A. Socquet, D. Keir, M. Kassim, A. Lemarchand, and G. C. P. King (2011), Seismicity during lateral dike propagation: Insights from new data in the recent Manda Hararo-Dabbahu rifting episode (Afar, Ethiopia), Geochem. Geophys. Geosyst., 12, Q0AB08, doi:10.1029/2010GC003434.

Gripp, A. E., and R. G. Gordon (2002), Young tracks of hotspots and current plate velocities, Geophys. J. Int., 150, 321361.

Hansen, S. E., A. A. Nyblade, and S. H. Benoit (2012), Mantle structure beneath Africa and Arabia from adaptively parameterized P-wave tomography: Implications for the origin of Cenozoic Afro-Arabian tectonism, Earth Planet. Sci. Lett., 319-320, 23-34.

Hardebeck, J. L., and P. M. Shearer (2002), A new method for determining first-motion focal mechanisms, Bull. Seismol. Soc. Am., 92, 2264-2276.

Heidbach, O., M. Tingay, A. Barth, J. Reinecker, D. Kurfeß, and B. Müller (2010), Global crustal stress pattern based on the World Stress Map database release 2008, Tectonophysics, 482, 3-15.

Hollnack, D., and R. Stangl (1998), The seismicity related to the southern part of the Kenya Rift, J. Afr. Earth Sci., 26, 477-495.

Huerta, A. D., A. A. Nyblade, and A. M. Reusch (2009), Mantle transition zone structure beneath Kenya and Tanzania: More evidence for a deep-seated thermal upwelling in the mantle, Geophys. J. Int., 177, 1249-1255.

Hutton, L. K., D. M. David, and M. Boore (1987), The ML scale in Southern California, Bull. Seismol. Soc. Am., 77, 6, 2074-2094.

Ibs-von Seht, M., S. Blumenstein, R. Wagner, D. Hollnack, and J. Wohlenberg (2001), Seismicity, seismotectonics and crustal structure of the southern Kenya Rift; new data from the Lake Magadi area, Geophys. J. Int., 146, 439-453.

Ibs-von Seht, M., T. Plenefisch, and K. Klinge (2008), Earthquake swarms in continental rifts-A comparison of selected cases in America, Africa and Europe, Tectonophysics, 452, 66-77.

Julia, J., C. J. Ammon, and A. A. Nyblade (2005), Evidence for mafic lower crust in Tanzania, East Africa, from joint inversion of receiver functions and Rayleigh wave dispersion velocities, Geophys. J. Int., 162, 555-569.
Keir, D., I. D. Bastow, K. A. Whaler, E. Daly, D. G. Cornwell, and S. Hautot (2009), Lower crustal earthquakes near the Ethiopian rift induced by magmatic processes, Geochem. Geophys. Geosyst., 10, Q0AB02, doi:10.1029/2009GC002382.

Keir, D., C. Pagli, I. D. Bastow, and A. Ayele (2011), The magma assisted removal of Arabia in Afar: Evidence from dike injection in the Ethiopian rift captured using InSAR and seismicity, Tectonics, 30, TC2008, doi:10.1029/ 2010 TC002785.

Kendall, J. M., S. Pilidou, D. Keir, I. D. Bastow, G. W. Stuart, and A. Ayele (2006), Mantle upwellings, melt migration and the rifting of Africa: Insights from seismic anisotropy, in The Afar Volcanic Province Within the East African Rift System, Geol. Soc., London, Spec. Publ. 259, 55-72, doi: 10.1144/GSL.SP.2006.259.01.06.

Kennett, B. L. N., and E. R. Engdahl (1991), Traveltimes for global earthquake location and phase identification, Geophys. J. Int., 105, 429-465.

Kohlstedt, D. L., B. Evans, and S. J. Mackwell (1995), Strength of the lithosphere: Constraints imposed by laboratory experiments, J. Geophys. Res., 100, 17,587-17,602.

Koulakov, I. (2009), LOTOS code for local earthquake tomographic inversion. Benchmarks for testing tomographic algorithms, Bull. Seismol. Soc. Am., 99, 194-214.

Langston, C. A., R. Brazier, A. A. Nyblade, and T. J. Owens (1998), Local magnitude scale and seismicity rate for Tanzania, East Africa, Bull. Seismol. Soc. Am., 88, 712-721.

Last, R. J., A. A. Nyblade, C. A. Langston, and T. J. Owens (1997), Crustal structure of the East African plateau from receiver functions and Rayleigh wave phase velocities, $J$. Geophys. Res., 102, 24,469-24,483.

Le Gall, B., P. Nonnotte, J. Rolet, M. Benoit, H. Guillou, M. Mousseau-Nonnotte, J. Albaric, and J. Déverchère (2008), Rift propagation at craton margin. Distribution of faulting and volcanism in the North Tanzanian Divergence (East Africa) during Neogene times, Tectonophysics, 448, 1-19.

Lindenfeld, M., and G. Rümpker (2011), Detection of mantle earthquakes beneath the East African Rift, Geophys. J. Int., 186, 1-5.

Lindenfeld, M., G. Rümpker, K. Link, D. Koehn, and A. Batte (2012), Fluid-triggered earthquake swarms in the Rwenzori region, East African Rift-Evidence for rift initiation, Tectonophysics, 566-567, 95-104.

Lohman, R. B., and J. J. McGuire (2007), Earthquake swarms driven by aseismic creep in the Salton Trough, California, $J$. Geophys. Res., 112, B04405, doi:10.1029/2006JB004596.

Lyakhovsky, V., A. Segev, U. Schattner, and R. Weinberger (2012), Deformation and seismicity associated with continental rift zones propagating toward continental margins, Geochem. Geophys. Geosyst., 13, Q01012, doi:10.1029/ $2011 \mathrm{GC} 003927$.

Macheyeki, A. S., D. Delvaux, M. D. Batist, and A. Mruma (2008), Fault kinematics and tectonic stress in the seismically active Manyara-Dodoma Rift segment in Central Tanzania-Implications for the East African Rift, J. Afr. Earth Sci., 51, 163-188.

Mainprice, D., and P. G. Silver (1993), Interpretation of SKSwaves using samples from the subcontinental lithosphere, Phys. Earth Planet. Inter., 78, 257-280.

McNamara, D. E., T. J. Owens, P. G. Silver, and F. T. Wu (1994), Shear wave anisotropy beneath the Tibetan Plateau, J. Geophys. Res., 99, 13,655-13,666.

Meade, C., P. G. Silver, and S. Kaneshima (1995), Laboratory and seismological observations of lower mantle isotropy, Geophys. Res. Lett., 22, 1293-1296. 
Michael, A. J. (1984), Determination of stress from slip data: Faults and folds, J. Geophys. Res., 89, 11,517-11,526.

Michael, A. J. (1987), Use of focal mechanisms to determine stress: A control study, J. Geophys. Res., 92, 357-368.

Mulibo, G. D., and A. A. Nyblade (2009), The 1994-1995 Manyara and Kwamtoro earthquake swarms: Variation in the depth extent of seismicity in Northern Tanzania, S. Afr. J. Geol., 112, 387-404.

Mulibo, G. D., and A. A. Nyblade (2013a), The P and S wave velocity structure of the mantle beneath eastern Africa and the African superplume anomaly, Geochem. Geophys. Geosyst., 14, 2696-2715, doi:10.1002/ggge.20150.

Mulibo, G. D., and A. A. Nyblade (2013b), Mantle transition zone thinning beneath eastern Africa: Evidence for a wholemantle superplume structure, Geophys. Res. Lett., 40, $3562-$ 3566, doi:10.1002/grl.50694.

Nicolas, A., and N. I. Christensen (1987), Formation of anisotropy in upper mantle peridotites-A review, in Composition, Structure and Dynamics of the Lithosphere-Asthenosphere System, vol. 16, edited by K.Fuchs and C.Froidevaux, pp. 111-123, AGU, Washington, D.C.

Nonnotte, P., H. Guillou, B. Le Gall, M. Benoit, J. Cotten, and S. Scaillet (2008), New K-Ar age determinations of Kilimanjaro volcano in the North Tanzanian Diverging rift, East Africa, J. Volcanol. Geotherm. Res., 173, 99-112.

Nyblade, A. A., and C. A. Langston (1995), East African earthquakes below $20 \mathrm{~km}$ depth and their implications for crustal structure, Geophys. J. Int., 121, 49-62.

Nyblade, A. A., H. N. Pollack, D. L. Jones, F. Podmore, and M. Mushayandebvu (1990), Terrestrial heat flow in East and South Africa, J. Geophys. Res., 95, 17,371-17,384.

Nyblade, A. A., C. Birt, C. A. Langston, T. J. Owens, and R. Last (1996), Seismic experiment reveals rifting of craton in Tanzania, Eos Trans. $A G U, 77,517$.

Nyblade, A. A., T. J. Owens, H. Gurrola, J. Ritsema, and C. A. Langston (2000), Seismic evidence for a deep upper mantle thermal anomaly beneath east Africa, Geology, 28, 599-602.

O'Donnell, J. P., A. Adams, A. A. Nyblade, G. D. Mulibo, and F. Tugume (2013), The uppermost mantle shear wave velocity structure of eastern Africa from Rayleigh wave tomography: Constraints on rift evolution, Geophys. J. Int., 194(2), 961-978, doi:10.1093/gji/ggt135.

Paige, C. C., and M. Q. Saunders (1982), LSQR: An algorithm for sparse linear equations and sparse least squares, $A C M$ Trans. Math. Software, 8, 43-71.

Perez-Gussinyé, M., M. Metois, M. Fernandes, J. Vergès, J. Fullea, and A. R. Lowry (2009), Effective elastic thickness of Africa and its relationship to other proxies for lithospheric structure and surface tectonics, Earth Planet. Sci. Lett., 287, 152-167.

Petit, C., and C. Ebinger (2000), Flexure and mechanical behavior of cratonic lithosphere: Gravity models of the East African and Baikal rifts, J. Geophys. Res., 105, 19,151-19,162.

Pik, R., D. Marty, and D. R. Hilton (2006), How many mantle plumes in Africa? The geochemical point of view, Chem. Geol., 226(3-4), 100-114, doi:10.1016/j.chemgeo.2005. 09.016.

Reyners, M., D. Eberhart-Phillips, and G. Stuart (2007), The role of fluids in lower-crustal earthquakes near continental rifts, Nature, 446, 1075-1078.

Ritsema, J., A. A. Nyblade, T. J. Owens, C. A. Langston, and J. C. VanDecar (1998), Upper mantle seismic velocity structure beneath Tanzania, east Africa: Implications for the stability of cratonic lithosphere, J. Geophys. Res., 103, 21,201-21,213.

Schmeling, H., and H. Wallner (2012), Magmatic lithospheric heating and weakening during continental rifting: A simple scaling law, a 2-D thermomechanical rifting model and the East African Rift System, Geochem. Geophys. Geosyst., 13, Q08001, doi:10.1029/2012GC004178.

Scholz, C. H. (2002), The Mechanics of Earthquakes and Faulting, pp. 508, Cambridge Univ. Press, Cambridge, U.K. Shudofsky, G. N., S. Cloetingh, S. Stein, and R. Wortel (1987), Unusually deep earthquakes in East Africa: Constraints on the thermo-mechanical structure of a continental rift system, Geophys. Res. Lett., 14, 741-744.

Sieminski, A., Q. Liu, J. Trampert, and J. Tromp (2007), Finitefrequency sensitivity of surface waves to anisotropy based upon adjoint methods, Geophys. J. Int., 168, 1153-1174.

Silver, P. G. (1996), Seismic anisotropy beneath the continents: Probing the depths of geology, Annu. Rev. Earth Planet. Sci., 24, 385-432.

Silver, P. G., and W. W. Chan (1988), Implications for continental structure and evolution from seismic anisotropy, Nature, 335, 34-39.

Silver, P. G., and W. W. Chan (1991), Shear wave splitting and subcontinental mantle deformation, J. Geophys. Res., 96, 16,429-16,454.

Smith, M., and P. Mosley (1993), Crustal heterogeneity and basement influence on the development of the Kenya Rift, East Africa, Tectonics, 12, 591-606.

Sommer, H. (2009), "Wet" low angle subduction: A possible mechanism below the Tanzania craton $2 \mathrm{Ga}$ ago, Mineral. Petrol., 96, 113-120.

Stamps, D. S., E. Calais, E. Saria, C. Hartnady, J. M. Nocquet, C. J. Ebinger, and R. M. Fernandes (2008), A kinematic model for the East African Rift, Geophys. Res. Lett., 35, L05304, doi:10.1029/2007GL032781.

Thybo, H., and C. A. Nielsen (2009), Magma-compensated crustal thinning in continental rift zones, Nature, 457, 873-876.

Um, J., and C. Thurber (1987), A fast algorithm for two-point seismic ray tracing, Bull. Seismol. Soc. Am., 77, 972-986.

Vidale, J. E., and P. M. Shearer (2006), A survey of 71 earthquake bursts across southern California: Exploring the role of pore fluid pressure fluctuations and aseismic slip as drivers, J. Geophys. Res., 111, B05312, doi:10.1029/ 2005JB004034.

Vinnik, L. P., L. I. Makeyeva, A. Milev, and A. Y. Usenko (1992), Global patterns of azimuthal anisotropy and deformations in the continental mantle, Geophys. J. Int., 111, 433-447.

Waldhauser, F., and W. L. Ellsworth (2000), A doubledifference earthquake location algorithm: Method and application to the northern Hayward fault, California, Bull. Seismol. Soc. Am., 90(6), 1353-1368.

Walker, K. T., A. A. Nyblade, S. L. Klemperer, G. H. R. Bokelmann, and T. J. Owens (2004), On the relationship between extension and anisotropy: Constraints from shear wave splitting across the East African Plateau, J. Geophys. Res., 109, B08302, doi:10.1029/2003JB002866.

Weeraratne, D. S., D. W. Forsyth, K. M. Fischer, and A. A. Nyblade (2003), Evidence for an upper mantle plume beneath the Tanzanian craton from Rayleigh wave tomography, $J$. Geophys. Res., 108(B9), 2427, doi:10.1029/2002JB002273.

Wiemer, S. (2001), A software package to analyze seismicity: ZMAP, Seismol. Res. Lett., 72, 373-382.

Wright, T. J., C. Ebinger, J. Biggs, A. Ayele, G. Yirgu, D. Keir, and A. Stork (2006), Magma-maintained rift segmentation at continental rupture in the 2005 Afar dyking episode, Nature, 442(7100), 291-294.

Wüstefeld, A., G. Bokelmann, C. Zaroli, and G. Barruol (2008), SplitLab: A shear-wave splitting environment in Matlab, Comput. Geosci., 34, 515-528. 